\title{
Yapılı Çevre Özellikleri ve Konut-Konut Çevresi Kullanıcı Memnuniyeti Etkileșimi: Kırklareli Merkez Örneği*
}

\author{
Interaction Between Built Environmental Characteristics and Housing-Housing \\ Environment User Satisfaction: The Case of Kırklareli City Centre
}

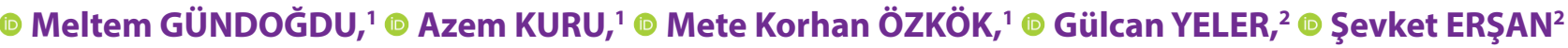

Öz

\begin{abstract}
Yaşam kalitesinin en önemli göstergelerinden biri olan konut ve çevresinin iyi planlanmış olması kullanıcı memnuniyetini arttırmaktadır. Kontrolsüz ve düzensiz kentsel gelişim ise, konut kullanım, konut çevresi fiziksel ve iklimsel konfor özellikleri, kentsel ortak kullanım ve sosyal donatı alanlarına erişilebilirlik, güvenlik, komşuluk gibi kullanıcı memnuniyetine doğrudan etki eden unsurları olumsuz yönde etkilemektedir. Bu nedenle, konut-konut çevresi memnuniyetinin değerlendirilmesinde kentsel mekan gelişimi ve yapılı çevre özelliklerinin bilinmesi önemlidir. Araştırma alanı olarak seçtiğimiz Kırklareli merkez ilçesinde düzensiz ve kontrolsüz bir mekansal gelişim görülmektedir. Kentsel mekân değişimleri, kentin birçok bölgesinde genellikle yapı yüksekliklerinin ve yapılaşma düzenlerinin farklılaşması ile tek parselde binaların yıkılıp yeniden yapılması olarak devam etmektedir. Kırklareli merkez ilçesi yapılı çevre özellikleri ile kullanıcıların memnuniyet düzeyleri arasındaki ilişkinin bilinmesi, bundan sonra yapılması düşünülen plan ihtiyaç ve taleplerinin belirlenmesi açısından önem arz etmektedir. Bu kapsamda araştırmanın amacı; Kırklareli kent merkezi yapııı çevre özellikleri ile konut-konut çevresi kullanıcı memnuniyeti arasındaki etkileşimin ve kullanııı beklentilerinin ortaya çıkartılması olarak belirlenmiştir. Yerinde yapılan analiz ve anket değerlendirmeleri sonucunda elde edilen verilerle ortaya konan bulguların, çalışma alanı kapsamında konut ve konut çevresinin sunduğu fiziksel koşullara ilişkin olarak konut, konut çevresi, yapı adası, kent, bölge ve üst ölçeklere doğru uzayıp giden çok boyutlu bir çerçevede çeşitli sorunları tanımlayabileceği düşünülmektedir.
\end{abstract}

Anahtar sözcükler: Kırklareli; konut-konut çevresi; kullanıc memnuniyeti; yapılı çevre.

One of the most important indicators of quality of life is the well-planned housing and the environment, which increases user satisfaction. The uncontrolled and irregular urban development adversely affects the elements that directly affect the user satisfaction, such as residential use, physical and climatic comfort characteristics of the residential environment, accessibility to urban common use and social reinforcement areas, security and neighborhood. For this reason, it is important to know the development of urban space and the built environment characteristics in the evaluation of housing-housing environment satisfaction. An irregular and uncontrolled spatial development is observed in the central district of Kırklareli, which we have chosen as the study area. Urban space changes continue to be the demolition and reconstruction of buildings in single parcels with differentiations of building heights and construction arrangements in many parts of the city. It is important to know the relationship between the built environment characteristics of the central district of Kırklareli and the satisfaction levels of the users, and to determine the plan needs and demands. In this context, the aim of the research; to find out the interaction between built environment features and user satisfaction of the housing-housing environment and user expectations in Kırklareli city center. It is believed that the findings of the data obtained from the analysis and survey evaluations in place can define various problems related to the physical conditions offered by the housing and housing environment within the scope of the study area in a multidimensional framework extending to the residential, residential environment, building island, city, region and upper scales.

Keywords: Kırklareli; housing-housing environment, user satisfaction, built environment.

* Bu çalışma, 2015 tarihinde başlanarak 2018 tarihinde tamamlanan "Kırklareli Merkez Bölgesi, Parselasyon ve Yapılaşma Şartları Değişiminin Araştırılması ve Etkilerinin Kullanıcı Memnuniyeti Açısından Değerlendirilmesi" başlıklı araştırma projesinden üretilmiştir.

'Kırklareli Üniversitesi Mimarlık Fakültesi, Şehir ve Bölge Planlama Bölümü, Kırklareli ${ }^{2}$ Kırklareli Üniversitesi Mimarlık Fakültesi, Mimarlık Bölümü, Kırklareli

Başvuru tarihi: 30 May 2018 - Kabul tarihi: 23 September 2019 İletişim: Azem KURU. e-posta: azemkuru@gmail.com 


\section{Giriş}

Rapaport, konutun bulunduğu yerden izole edilmiş, ayrı olarak düşünülemeyeceğini; aksine bireyler, komşular ve konut alanındaki imkânların konut yerleşim sistemini oluşturduğunu belirtmektedir (Rapaport, 1977). Konutun mekânsal kurgusunun oluşumundaki en önemli etmen kullanıcı/kullanıcıların gereksinmeleri, yaşam biçimleri ve konuttan beklentileridir (Zorlu ve Sağsöz, 2010:190). Konutlar, kullanıcılar için güvenlik, konfor ve bireyselliğin sembolüdür. Konut çevresi, konut ve/veya konut topluluğunda yaşayanların gereksinimlerinin karşılanması, sosyopsikolojik tatminin sağlaması açısından temel bir yaşam bölgesini oluşturmaktadır Konut ve konut çevresi aynı zamanda kavramsal açıdan hem konutu hem de kullanıcısı ile birlikte, toplumsal çevreyi içeren bir olgudur (Kellekci, ve Berköz 2006:168). Fiziksel, ekonomik, psikolojik ve sosyokültürel çevre içinde yer alan konut ve konutun içinde yer aldığı çevrede oluşan sorunlar, yaşayanların tatminini ve davranışını etkilemekte; mutluluk ve refah üzerinde olumsuz etkiler yaratabilmektedir (Güreman 2011:25). Konut ve çevresine dair performans değerlendirirken uygun ölçütler ve kriterler geliştirilmek zorunludur.

Memnuniyet konut değerlendirmelerinde kullanılan bir kavramdır. Konutta memnuniyet kavramı, konutun fiziksel standartlarının üzerinde oluşabilecek bir insan-çevre etkileşiminin düzeyini tanımlamaktadır. Konutta memnuniyet çevresel ve yaşamsal kalitenin bir göstergesidir (Yıldız ve Ulusoy, 2014:2). Kullanıcının kendi yaşam alanını ve konut çevresini önemsemesi ve değerlendirmesi, konut ve konut çevresi gereksinim ve beklentilerin belirlenmesinde temel araçlardan biridir (Kellekci, ve Berköz 2006:169). Hızlı ve kontrolsüz kentsel gelişim, günümüz kentlerinde kullanıcıların içinde bulundukları ortamlara ilişkin değerlendirmeleri daha da önemli hale getirmektedir. Bu bağlamda kullanıcı katılımı ve memnuniyet değerlendirmesi, konut uygulamaları ve kentsel altyapının geliştirilmesinde bir yöntem olarak karşımıza çıkmaktadır (Önder vd., 2010:20). Konut-konut çevresi kullanıcı memnuniyeti, kullanıcı özellikleri, konut kullanım özellikleri, konut çevresi fiziksel özellikleri, konut çevresi iklimsel konfor özellikleri gibi etkenlerin ve değişkenlerin birbiri ile etkileşiminde farklılaşma gösterebilmektedir.

Yaşam kalitesinin en önemli göstergelerinden biri olan konut ve çevresinin iyi planlanmış olması, kullanıcı memnuniyetini arttırmaktadır (Bölen ve Diğ., 2006). Kontrolsüz ve düzensiz kentsel gelişim ise, konut kullanım, konut çevresi fiziksel ve iklimsel konfor özellikleri, kentsel ortak kullanım ve sosyal donat alanlarına erişilebilirlik, güvenlik, komşuluk gibi kullanıcı memnuniyetine doğrudan etki eden unsurları olumsuz yönde etkilemektedir. Bu nedenle, konut-konut çevresi memnuniyetinin değerlendirilmesinde kentsel mekan gelişimi ve yapılı çevre özelliklerinin bilinmesi önemlidir.
Araştırma alanı olarak seçtiğimiz Kırklareli merkez ilçesinde düzensiz ve kontrolsüz bir mekânsal gelişim görülmektedir. Kentsel mekân değişimleri, kentin birçok bölgesinde genellikle yapı yüksekliklerinin ve yapılaşma düzenlerinin farklılaşması ile tek parselde binaların yıkılıp yeniden yapılması olarak devam etmektedir. Günümüzde halen Kırklareli kent merkezi için geçerli olan imar planı 1991 yılı onanlı 1/5000 ölçekli Nazım İmar Planı ve 1/1000 ölçekli Revizyon Uygulama İmar Planıdır. 1991 yılından bugüne geldiğimizde aradan geçen yaklaşık 25 senelik bir zaman aralığında, yeni bir nazım ve uygulama imar planı yapılmamıştır. Bu süreçte kentsel gereksinimler, parsel ölçeğinde talepler ve baskılar, genelde plan değişiklikleri ile uygulama yapılmasına yönlendirmiştir. Bu açıdan değerlendirildiğinde Kırklareli Merkez ilç̧e konut çevresi fiziksel özellikleri ile kullanıcıların memnuniyet düzeyleri arasındaki ilişkinin bilinmesi, hazırlanması gereken bütüncül plan ihtiyaç ve taleplerinin belirlenmesi açısından önem arz etmektedir.

Araştırmanın amacı; Kırklareli kent merkezi yapılı çevre özellikleri ile konut-konut çevresi kullanıcı memnuniyeti arasındaki etkileşimin ve kullanıı beklentilerinin ortaya çıkartılması olarak belirlenmiştir.

Bu amaçla araştırma çalışması iki bölümde ele alınmıştır. Çalışmanın birinci bölümünde Kırklareli merkez ilçe merkez bölgesi mer'i plan yapılanması incelenmiş olup, konut ve çevresi kullanım özelliklerini etkileyen parsel bazında plan değişikliklerinin dönemsel olarak dağılımına göre analizlerin ve kullanıcı memnuniyetine ilişkin anket çalışmalarının yapılacağı örneklem bölgeler belirlenmiştir.

Çalışmanın ikinci bölümünde seçilen örneklem bölgelerde analiz ve anket çalışmaları tamamlanmış, çıkan sonuçlar ve bu sonuçların karşılaştırmaları yapılarak, Kırklareli kent merkezi yapılı çevre özellikleri ile kullanıcıların konut ve konut çevresi memnuniyeti arasındaki ilişkinin nasıl olduğuna dair bulgular, kullanıcı tercih ve ihtiyaçları ortaya çıkartılmıştır.

Yerinde yapılan analiz ve anket değerlendirmeleri sonucunda elde edilen verilerle ortaya konan bulguların, çalışma alanı kapsamında konut ve yaşam çevresinin sunduğu fiziksel koşullara ilişkin olarak konut, konut çevresi, yapı adası, kent, bölge ve üst ölçeklere doğru uzayıp giden çok boyutlu bir çerçevede çeşitli sorunları tanımlayabileceği düşünülmektedir. Çalışmanın planlama ve tasarım süreçlerinde karar vericiler için önemli bir veri oluşturacağı, kullanıcıların konut ve çevresine dair memnuniyetinde etkili olan faktörlerin göz önünde bulundurularak, kimlikli bir mimari anlayışla daha yaşanabilir ve kaliteli çevreler oluşturulması sürecine katkı sağlayacağı öngörülmektedir.

\section{Yapılı Çevre Özellikleri İle Konut-Konut Çevresi Kullanıcı Memnuniyeti Arasındaki İlişki}

Konut ve konut çevresi fiziksel özellikler; bir yapının bulunduğu yapı adalarının boyut ve biçimleri ile birlikte, diğer 
yapı adaları ile ilişkisi, sosyal donatı alanlarının konum ve erişilebilirliği ve kentsel yerleşim içinde binaların tek tek ve birbirlerine göre konumlanmalarıla tanımlanan bina yükseklikleri, yapı düzeni, ada-parsel oranları, bina hacimleri gibi kentsel biçim özelliklerini kapsamaktadır (Ünlü, 2006:65). Plan tadilatları ve plana aykırı yapılaşmayla gerçekleşen konut ve çevresi fiziksel mekândaki değişimler, kısa vadede kullanıcı için ekonomik ve sosyal refah arttırıcı nitelikte algılanmasına rağmen uzun vadede ortak mekân ve donatı alanlarında yetersizlik, yapıların iklimsel konforlarının bozulması, mahremiyet ve komşuluk ilişkilerinin ortadan kalkmasına sebep olan bir konut-konut çevresi yapılanmasını da beraberinde getirebilmektedir.

$\mathrm{Bu}$ nedenle, kullanıcı memnuniyetinin belirlenmesine etki eden unsurlara ilişkin, yaşayanların görüş, düşünce, talep ve ihtiyaçlarının belirlenmesinin yanında, konut-konut çevresi mekânsal özelliklerinin gözlem ve analiz yöntemleriyle anlaşımasına da ihtiyaç vardır. Bu kapsamda; varsa plan tadilatları ve/veya plana aykırı yapılaşma, yoğunluk değerleri, yapı düzeni değişimi, kat adetleri, arazi kullanımı, sosyal donat alanları, teknik alt yapı olanakları, ortak kullanım alanları varlığını belirlemede mer'i planlara uygunluk değerlendirmesi kullanılabilir. Doluluk-boşluk değerlendirmeleri; ada-parsel büyüklükleri ve oranlarının, yapı-yol/sokak ilişkisinin anlaşılmasında, yapıların birbirlerine göre konumlarını, yapı yoğunluklarını saptamada kullanılabilir. Bu değerlendirmeler ile birlikte yapının yerleştiği eğim, yön, aldığı rüzgâr yönü ile yapılan değerlendirmeler ise yapının doğal aydınlanma ve havalandırmadan nasıl faydalanıldığına ilişkin bilgileri verecektir. Bu bağlamda ele alındığında; yapılı çevre analizleriyle ortaya çıkan mekânsal özellikler ile kullanıcı memnuniyetinin belirleyici unsurları arasında bir etkileşim bulunmaktadır.

Mer'i plana uygun olarak gelişim, bir kentsel alanın tamamı için öngörülen nüfusa yeterli kentsel donatı ve yerleşim alanı ihtiyacı ile belirlenen yapı düzeni, yapı yoğunluğu ve kat adetleri uyumlu, düzenli bir kentsel gelişimi ifade etmekte olup, kullanıc memnuniyetinde belirleyici etmenlerdendir. Arazi kullanım özelliklerinde sosyal donatı alanları varlığı ve bu alanlara kolay erişebilirlik ve yapı konum özellikleri kullanıcı memnuniyetini olumlu yönde etkileyecektir. Yapı-boş alan oranlarında, boş alanın yüksek olması konutların daha ferah ve aydınlık içinde olmasını sağlar. Kullanıcılar için genişlik, ferahlık hissi oluşturur, ortak kulIanım alanlarının varlığını gösterir. Aynı zamanda mahremiyeti sağlayarak, memnuniyete olumlu yönde etki edecektir. Yapının taban alanı (TAKS) oranının imar planına aykırı olarak yüksek olması, yapı yoğunluğunu arttırıcı ve yaşam konforunu azaltıcı niteliktedir. Bu durum kullanıcı dolaşımı ve açık alan kullanımı açısından olumsuz etkidedir. Yapının konumu, aldığı rüzgâr yönü, yapı mesafelerinin birbirine yakın olması, yapı kat yükseklikleri ile birlikte değerlendiril- diğinde, doğal aydınlanma ve hava sirkülasyonunu engelleyici etkide olabilmektedir. Bu da kullanıcı memnuniyetinde önemli olan konut ve çevresi iklimsel konfor özelliklerinin olumsuz yöndeki etkisini arttracaktır.

Yapılı çevre özellikleri ile konut-konut çevresi kullanıcı memnuniyeti arasında nasıl bir ilişki olduğunun bilinmesi, kullanıcı tercihleri ve beklentilerinin daha rasyonel olarak anlaşılmasını sağlayacaktır.

Kullanıcı anketinin şekillenmesinde, bu kavramsal çerçeve ile birlikte kullanıcı memnuniyetiyle ilgili yapılan bazı araştırmalar ön plana çıkmaktadır. Dülgeroğlu ve diğ. (1996)'nın yaptığı araştırma çalışmasında; toplu konutlarda niteliksel değerlerin incelenmesi ve genel sonuçlara ulaşmak için konutun beğenilen özellikleri, eylemler ve mekânsal performans, konut ve yakın çevresine ilişkin değerlendirmeler, konutta şikâyet edilen konular, beğenilen ve şikâyet edilen konuların karşılaştrııması, konutta yapılan ve yapılmak istenen değişiklikler bağlamında irdelenmiştir. İmamoğlu (1996), Ankara'daki toplu konut bölgelerinde "insan, konut ve çevre" değişkenlerinin değerlendirildiği bir araştırmada, sosyal psikolojik ve mimari açıdan disiplinler arası bir anlayışla, psikolojik, sosyal-ekonomik ve fiziki boyutların etkileşimini içeren genel bir sistem anlayışı ele alınmıştr. Farklı toplu konut bölgelerinde farklı sosyoekonomik düzeyde 874 kişiyle yapılan çalışmada, (1) hane halkının ve konutun genel özellikleri, (2) görüşülen kişinin evi, fiziki çevresi, komşuları ve mahallesine ilişkin algı ve değerlendirmeleri, (3) kent yasamı, konut ve çevreye ilişkin genel tutum ve yargıları konuları temel alınmıştr. Kellekci ve Berköz (2006), çalışmalarında konut ve çevresel kalite memnuniyetini arttran faktörlerin saptanması için, İstanbul Metropoliten Alanı'nda planlı gelişen toplu konut alanlarında yapılan anketleri faktör analizi tekniğiyle değerlendirmişlerdir. Bunlar kolay erişilebilirlik, çevresel kalite değişkenleri, çevrenin güvenliği, komşuluk ilişkileri, konut çevresi görünümü ve ekonomik değer ile ilgili faktör gruplarıdır. Berköz (2008), İstanbul'da korunaklı tek ailelik/ müstakil konutlar üzerine bir çalışma yapmış ve üst gelir grubunun yaşadığı tek-aile konutlarından oluşan korunaklı yerleşimlerin mekânsal yer seçimi tercihleri, kentsel donatılarının, erişilebilirlik açısından değerlendirilmesi ve kullanıcılarının konut ve çevresinden memnuniyetlerinin belirlenmesine yönelik bir alan çalışması yapmıştr. Güreman'ın (2016), Amasya kentinde yaptı̆ı̆ çalışmasında, konut çevresi ve konut seçiminde kullanıcıların tercihinde etkili olan değişkenlerin bireylerin davranışlarına ne ölçüde yansıdığı konu edilmiştir.

Incelenen literatür örneklerinde konut kullanıcılarının sosyo-ekonomik profili ve ikamet ettikleri konutun temel yapısal özellikleri değerlendirilmiş olup; bu araştırma, literatür çalışmalarından farklı olarak yapılı çevredeki değişim olgusunu-konut kullanıcı memnuniyeti ile ilişkilendirerek 
detaylandırılmış analizler ile (arazi kullanım, mer'i plana uygunluk, iklim, TAKS/KAKS analizi vb.) desteklemektedir.

\section{Materyal ve Yöntem}

Araştirmada bilgi-belge tarama, analiz ve anket yöntemlerinden faydalanılmıştır. Bilgi ve belgeler için 1984 yılından günümüze Kırklareli kent merkezine yönelik çalışmalar derlenmiştir. Kırklareli Belediyesi'nden temin edilen 1/1000 ölçekli halihazır harita 2006 yılı onanlı olduğu için, araştırma projesinin başlangıç dönemi olan 2015 yılında yapılan tespitlerle güncellenmiş, analizler için bu altlık kullanılmıştı. Ayrıca Kırklareli Belediyesi'nde 2016 yılında yapılan arşiv taraması sonucunda düzenli olarak kayıtları tutulan ve bilgilerine ulaşılabilen 1995-2000 ve 2010-2015 arası dönemleri kapsayan plan tadilatlarına ulaşılabilmiş, bu tadilatlar yorumlanmıştır. Araştırma çalışmasında, seçilen örneklem bölgelerde yapılı çevre özelliklerinin anlaşılabilmesi için mer'i plan değerlendirmesi ile arazi kullanımı, kat yüksekliği, boşluk-doluluk, TAKS, KAKS ve gölgelenmehava sirkülasyonu analizleri yapılmış ve konut-konut çevresi kullanıc memnuniyetine ilişkin anket çalışması uygulanmıştir.

Mer'i plan değerlendirmeleri halen yürürlükte olan ve birçok plan değişikliği işlemine konu edilmiş 1991 onay tarihli Kırklareli Revizyon Uygulama İmar Planı üzerinden yapılmıştır. Mevcut durum işlevsel özellikler, kat yüksekliği, boşluk-doluluk, TAKS/KAKS analizleri için yerinde arazi kullanım çalışması yapılmıştır.

Konut çevresi iklimsel konfor özelliklerinin belirlenebilmesinde gölgelenme analizi için; (Mississagua, 2014:8-9) kaynağında belirtilen standart gün ve saat değerleri kullanılmıştr. Buna göre, temel günlerin 21 Mart (ilkbahar ekinoksu), 21 Haziran (yaz gündönümü), 23 Eylül (sonbahar ekinoksu), 21 Aralık (kış dönümü) olarak; saat aralıklarının ise güneş doğumundan 1,5 saat sonrası ve güneş batışından 1,5 saat öncesi alınması gerekmektedir. Sketch Up Pro 2017 programında örneklem bölgelerinin üç boyutlu modelleri hazırlanmış ve Kırklareli kent merkezi koordinatın$\mathrm{da}$, UTC +3.00 zaman diliminde, belirlenen saat ve tarihlerde (Tablo 1) simülasyonlar uygulanmıştır.

Hava sirkülasyon analizi için, Sketch Up Pro 2017 programında örneklem bölgeler için üç boyutlu modeller hazırlanmış, Autodesk Flow Design 2014 programında tanımlı olan sanal rüzgar türbininde Kırklareli kent merkezi için elde edilen rüzgar hızı ve rüzgar yönleri için simülasyonlar uygulanmıştir.

Anket çalışması için yapılması gereken anket sayısı, seçilen örneklem alanların bulunduğu mahallelerde yaşayan 2015 nüfus verilerine göre belirlenmiştir. Aile büyüklüğü 3,4 kişi (TÜik, 2016) olarak alınmış, \%5 örneklem büyüklügü ile Karacaibrahim Mahallesi'nde (A Bölgesi) 61 birimle, Karakaş Mahallesi'nde (B Bölgesi) 130 konut kullanımlı bağımsız bölümle toplam 191 adet anket yapılmıştr. Bölgelerde bulunan tüm konut yapılarında kat yüksekliği ve yapı yoğunluğu hesaplanarak, her yapıda bulunan birime göre eşit oranlarda anket yapılmasına dikkat edilmiştir.

Anket soruları üç bölümde ele alınmıştrr. Birinci bölümde, nesnel belirleyici bilgilere ulaşmak için kullanıcı ve konut özeliklerine ilişkin sorular hazırlanmıştır. Bu doğrultuda anket yapılan kullanıcıya ilişkin cinsiyet, yaş, eğitim, meslek, aile büyüklüğü, gelir durumu, mal sahipliği, kaç senedir bu binada yaşadığı, daha önce ikamet edilen yer bilgileri çoktan seçmeli olarak alınmıştır. Yaşanılan konut özelliğine ilişkin yapının yaşı, binanın kat adeti, konut büyüklüğü, oda sayısı bilgileri alınmıştır. Ayrıca bölgede yaşam alanlarında memnuniyeti etkileyen yapının konumlanışı, yaşam alanı özellikleri, ısıtma - soğutma sistemi ve ısıtma ve soğutma amaçlı yaz-kış sarf miktarı soruları sorulmuştur.

i̇kinci bölüm, konut-konut çevresi memnuniyetine etki eden unsurların ve yapılı çevre özelliklerinin Kırklareli kent merkezi yaşayanları üzerindeki etkisinin belirlenmesi amacıyla düzenlenmiştir. Konut memnuniyeti; konum, büyüklük, konut içi mekân yerleşimi, işlevsellik, kullanışılıı, iç mekân konfor koşulları, mekânların güneş ışığı alması, havalandırılması, yalıtım, dış görünüm, manzara konularını başlıklar altında sorgulanmıştir. Konut çevresi memnuniyeti için kullanıılardan konutlarının bulunduğu çevreyi çeşitli sorular bağlamında değerlendirmesi istenmiştir. Bunlar; binalar arasındaki mesafe, sokak genişlikleri, mahremiyet, binaların güneş alışı, yeşil alan, çocuk oyun alanı, araç park yerlerinin varlığı, araç güvenliği, insan ve konut güvenliği, komşuluk ilişkileri, merkeze erişebilirlik, eğitim alanlarına, sağlık alanlarına, açık alanlara, eğlence alanlarına, alışveriş alanlarına ve toplu-taşıma duraklarına erişebilirlik şeklindedir.

Son bölümde, kullanıcıların konut - konut çevresi tercih ve beklentilerine ilişkin değerlendirmeleri alınmıştır Sorular çoktan seçmeli, beşli likert ölçeğinde "çok memnun, memnun, normal, az memnun ve hiç memnun değil" şeklinde

Tablo 1. Örneklem bölgeleri gölgelenme analizi tarih ve saat bilgileri

\begin{tabular}{lll}
\hline 21 Mart 2018 (ilkbahar ekinoksu) & Sabah: 09.00 & Akşam: 18.00 \\
21 Haziran 2018 (yaz gündönümü) & Sabah: 07.00 & Akşam: 19.00 \\
23 Eylül 2018 (sonbahar ekinoksu) & Sabah: 08.30 & Akşam: 17.30 \\
21 Aralık 2018 (kış gündönümü) & Sabah: 10.00 & Akşam: 16.00 \\
\hline
\end{tabular}


ve olumlu/olumsuz cevaplar şeklinde düzenlenmiştir. Anket çalışması veri sonuçlarının dökümünde SPSS 23.0 programında frekans ve çapraz sorgu analizleri kullanılmıştır.

\section{Çalışma Alanı Konum ve Mekânsal Gelişim Özellikleri}

Kırklareli, Marmara Bölgesi'den Avrupa'ya geçiş alanında ve Bulgaristan ile komşu bir sınır ilidir (Şekil 1).

Kırklareli Merkez ilçede yerleşim ilk olarak Yayla Mahallesi ve Kırklar Tepesi olmak üzere iki noktada başlamıştr. Zaman içinde genişleyen kent ilk yerleşimin başladığı çevresine nazaran yüksek iki hâkim tepenin eteklerinden ovaya doğru gelişmiştir (Tuncel, 2002:480). Kırklareli kent merkezi yükselti analizi incelendiğinde kentin denizden yüksekliğinin ortalama $220 \mathrm{~m}$. olduğu görülmektedir. Kent $178 \mathrm{~m}$. yükseklik ile $265 \mathrm{~m}$. yükseklik arasına yerleşmiştir. Bununla birlikte yerleşimin genellikle düz ve düze yakın eğimli arazi üzerine kurulduğu gözlenmektedir. Yerleşik alanın büyük çoğunluğunda eğim derecelerinin yüzde 2'nin altında kaldığı çok az bir yerleşik alanın yüzde 10 eğimden fazlasına sahip olduğu görülmektedir (Şekil 2).

Topografya itibariyle çok hareketli bir yapıya sahip olmayan kentin makroformunu büyük ölçüde kenti çevre yerleşimlere bağlayan; Edirne, Pınarhisar, Babaeski ve son yıllarda üniversite yerleşkesinin konumlanmasıyla önem kazanan Kofçaz Karayolu güzergâhları şekillendirmiştir. Bununla birlikte TOKi Konutları Çağdaşkent, Murat Sitesi gibi büyük ölçekli konut projeleri, küçük sanayi sitesi, askeri tesisler, Karahıdır Meslek Yüksek Okulu ve Kredi Yurtlar Kurumu öğrenci yurdu gibi büyük ölçekli kamu yatırımları kentin mekânsal gelişimini yönlendiren önemli unsurlardır. Günümüzde tek merkezli bir kent olan yerleşimde Cumhuriyet ve Vilayet meydanları büyük oranda ticaret odaklarını oluşturmaktadır. Kentin arazi kullanım yapısını büyük oranda kentsel donat alanları şekillendirmektedir. Özellikle il merkezi olması sebebiyle çeşitli bakanlıkların il teşkilatları ve Valilik kent merkezinin arazi kullanım yapısında baskın karakterdedir (Şekil 3).

Kent merkezinde formu belirleyen önemli akslar; M. Kemal Bulvarı, İstiklal Caddesi, 100. Yıl Caddesi, Cumhuriyet Caddesi, Kara Umur Caddesi, Hastane Caddesi İstasyon Caddesi, Sungurbey Caddesi, Eriklice Caddesi, İnönü Caddesi, Waldorf Caddesi ve Öztürk Bulvarı ve Fevzi Çakmak Bulvarıdır (Şekil 4).

\section{Mer'i Plan Durumu ve Örneklem Bölgelerin Seçimi}

Kentin ilk imar planı 1948 yılında Muallim Seyfi Arıkan tarafindan $1 / 500$ ve $1 / 1000$ ölçeklerde yapılmış ve mülki-

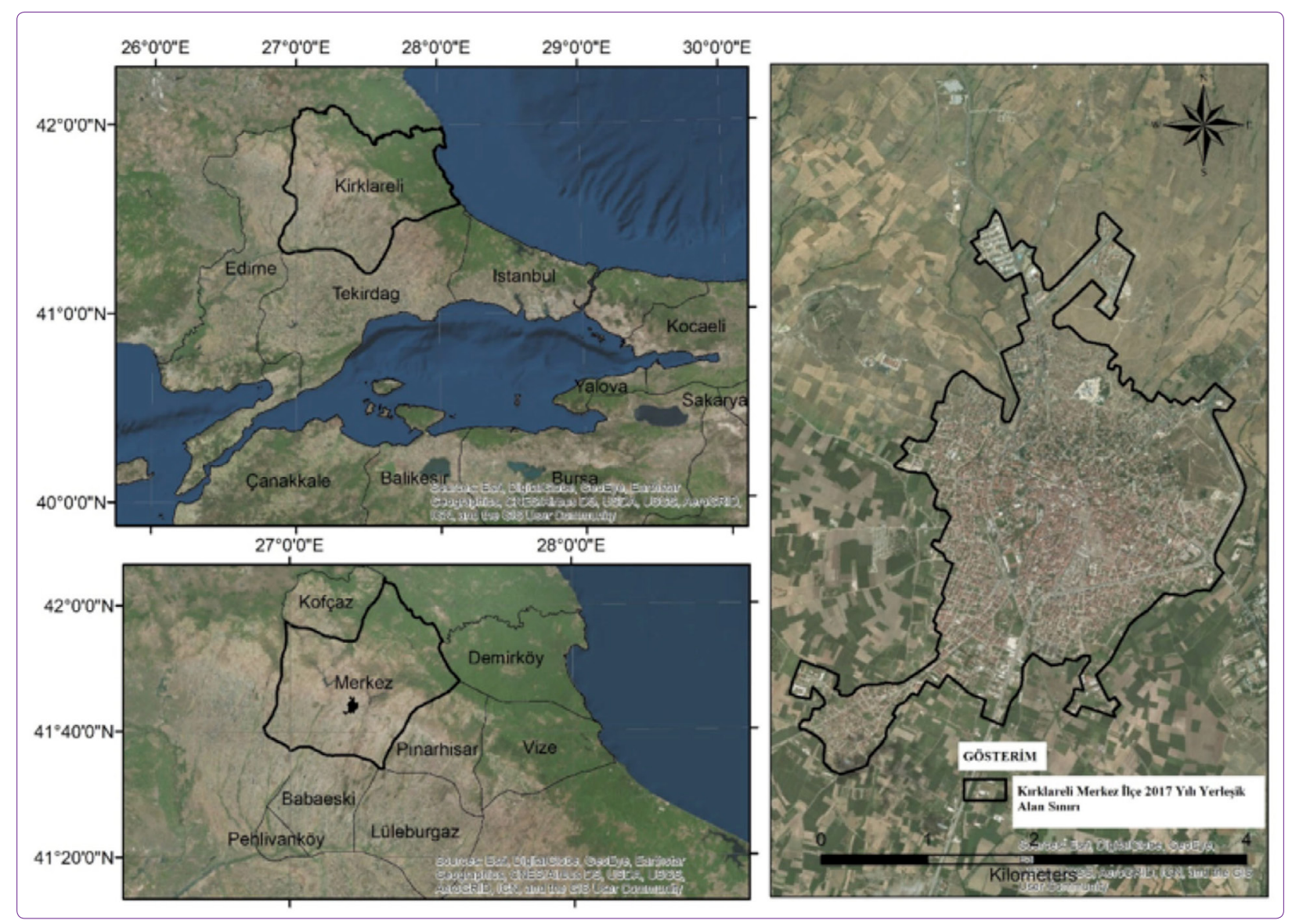

Şekil 1. Kırklareli konum haritası (güncel uydu görüntüsü altlık olarak kullanılmıştır). 


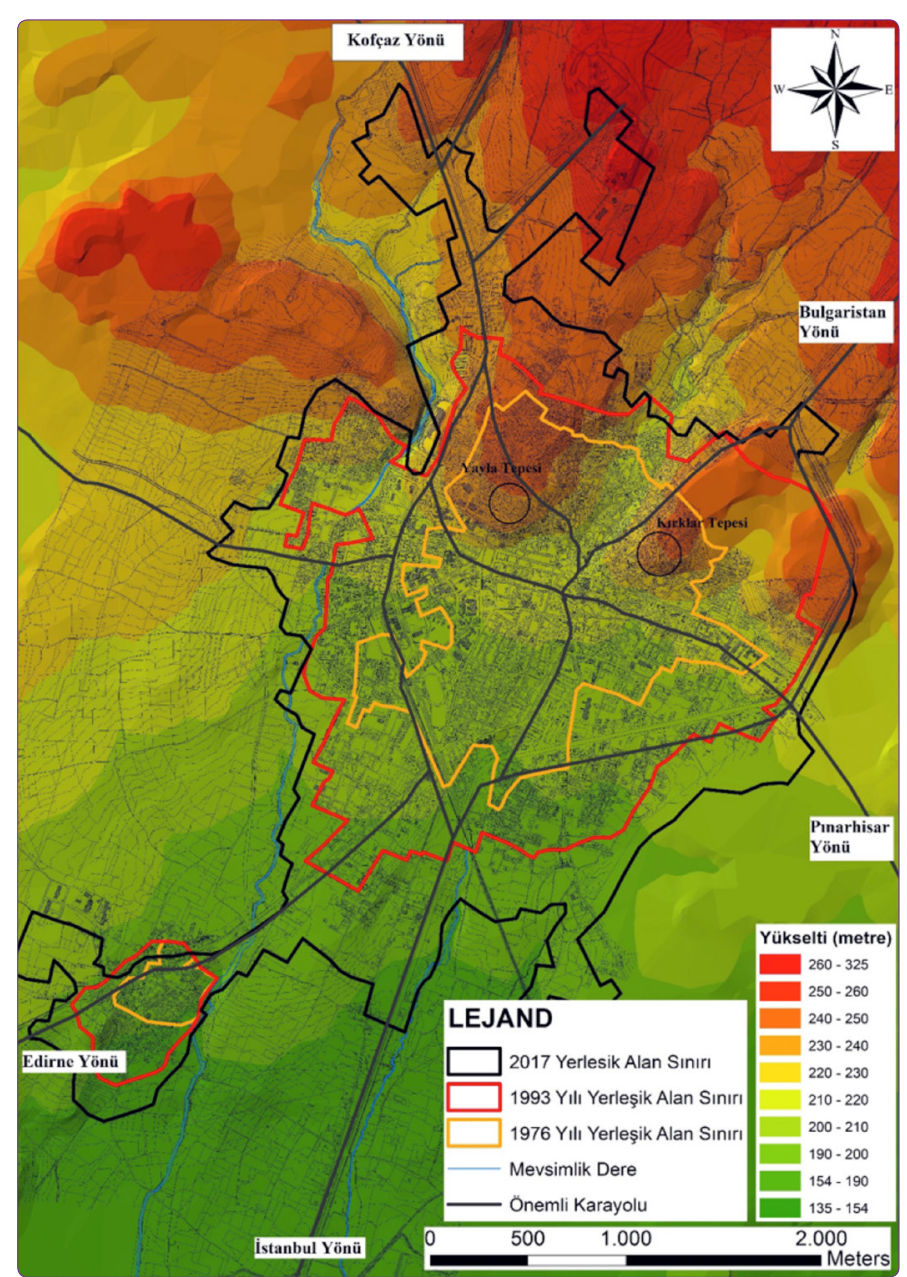

Şekil 2. Kırklareli kent makroformunun gelişimi (Uydu görüntüleri ve hava fotoğrafları kullanılarak üretilmiştir).

yet-konut düzeni temelinde kararlar getirmiş, mülkiyet dokusu kısmen korunmaya çalışıımıştır (Aysu ve diğ., 1984; MGSÜ, 1991). Kentin ikinci imar planı 1968 yılında Mimar Fikret Cankut tarafindan $1 / 1000$ ve $1 / 2000$ ölçeklerde yapılmış ve temel olarak yine mülkiyet-konut düzeni ile ulaşım bağlantıları temelinde kararlar getirmiştir. 1968 onanlı imar planları, Kırklareli kent merkezinin günümüzdeki formunun şekillenmesini sağlayan plan olup, kent bu plan döneminde gelişme konut alanları ile beraber batı ve güney yönünde büyüme göstermiştir (Aysu ve diğ., 1984; MGSÜ, 1991). Kentin üçüncü imar planı 1986 yılında Yıldız Teknik Üniversitesi, Şehir ve Bölge Planlama Bölümü tarafindan kent merkezi ve çevresini kapsayan 1048 hektarlık alan için 1/1000 ve 1/5000 ölçeklerde hazırlanmış, 1989 ve 1991 yıllarında Kırklareli Belediyesi tarafindan revize edilmiştir. İmar tüzesinin gereklerine karşın imar planı revizyonları 1/1000 ölçekte yapılmıştır. Günümüzde halen Kırklareli kent merkezi için geçerli olan imar planı 1991 yılı onanlı Revizyon Uygulama İmar Planı'dır. 1991 yılından günümüze aradan geçen zaman içinde kent bütününü kapsayan imar planlarının yapılmadığı görülmektedir. Merkezi ve yerel yö-

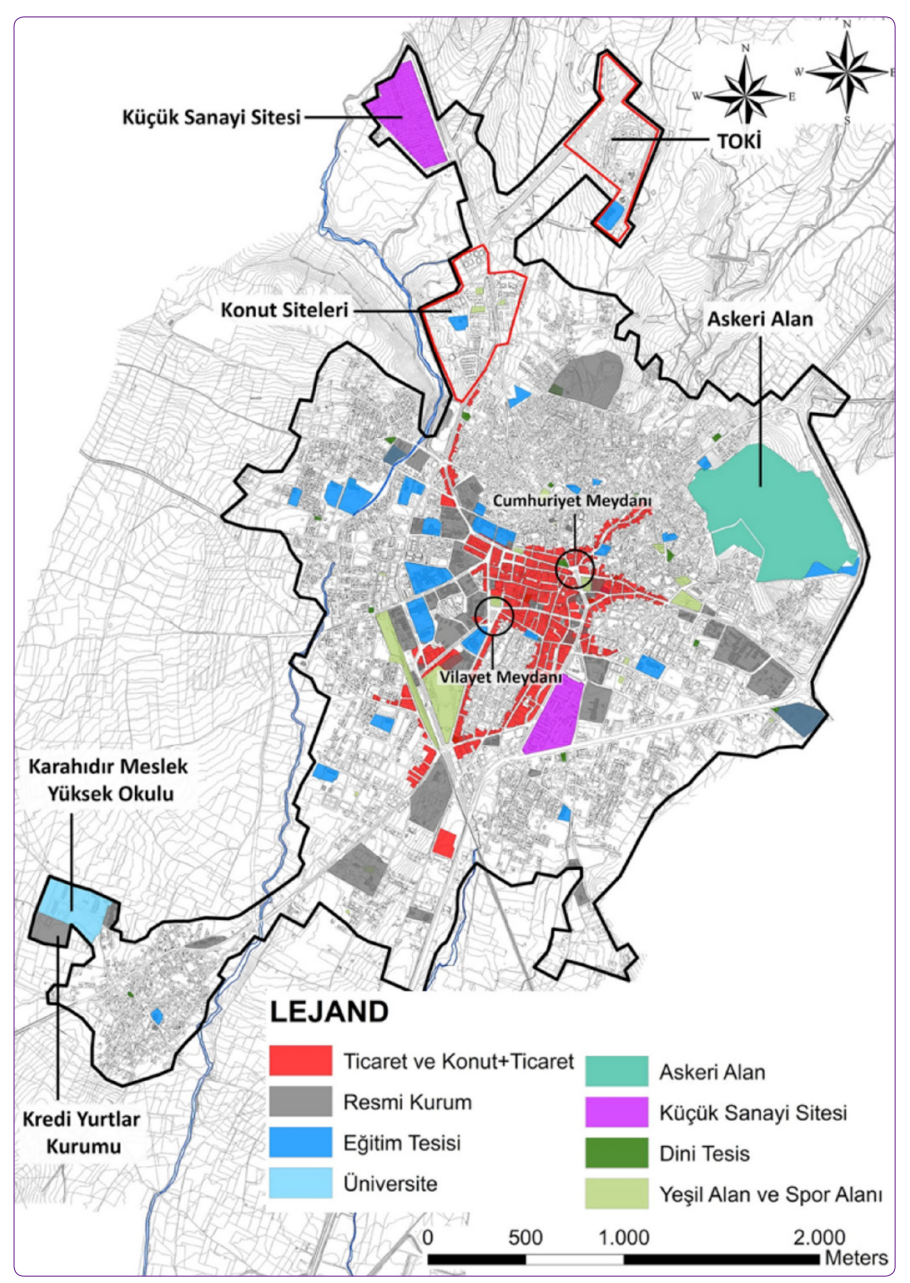

Şekil 3. Kırklareli kentinin arazi kullanımı.

netimlerin bu süreçte kontrol ve denetim araçlarını kullanmaması sonucunda, kentsel gereksinimler parsel ölçeğinde talepler ve baskılar neticesinde plan tadilatları, ıslah imar planları ve mevzi planlar gibi parçacıl uygulamalarla karşılanmaya çalışılmıştır. 1991 onanlı Revizyon Uygulama İmar Planı sonrasında hazırlanmış olan, 1992-1995-1998-1999 onanlı beş adet ıslah imar planı ve 2001 tarihinde Kırklareli Kentsel Sit Alanı (Yayla Mahallesi) Koruma Amaçlı İmar Planı kentsel mekânı etkileyen diğer planlardır. Diğer yandan 1991 onanlı Revizyon İmar Planına zaman içinde bazı ilave imar planları eklenmiş ve makroform bölgesel ilave imar planları yoluyla şekillenmiştir. 208 hektarlık bir alanı kapsayan 06.10.1995 onanlı Kırklareli Küçük Sanayi Siteleri imar planı, 05.06.2007 onanlı TOKi Cumhuriyet Mahallesi ilave İmar Planı mevcut imar planına eklemlenen ve kentsel gelişimi yönlendiren ilave imar planlarıdır. Üst ölçekte bölgeye ilişkin 2009 onanlı 1/100.000 ölçekli Trakya Ergene Havzası Revizyon Çevre Düzeni Planı ve 2012 onanlı 1/25.000 ölçekli Kırklareli Çevre Düzeni Planı hazırlanarak yürürlüğe girmiştir (Gündoğdu ve Altnn 2015:289). Üst ölçekte plan kararlarına uygun yeni ve bütüncül bir imar planı hazırlanması gereğine karşın, henüz böyle bir çalışma gerçekleşti- 


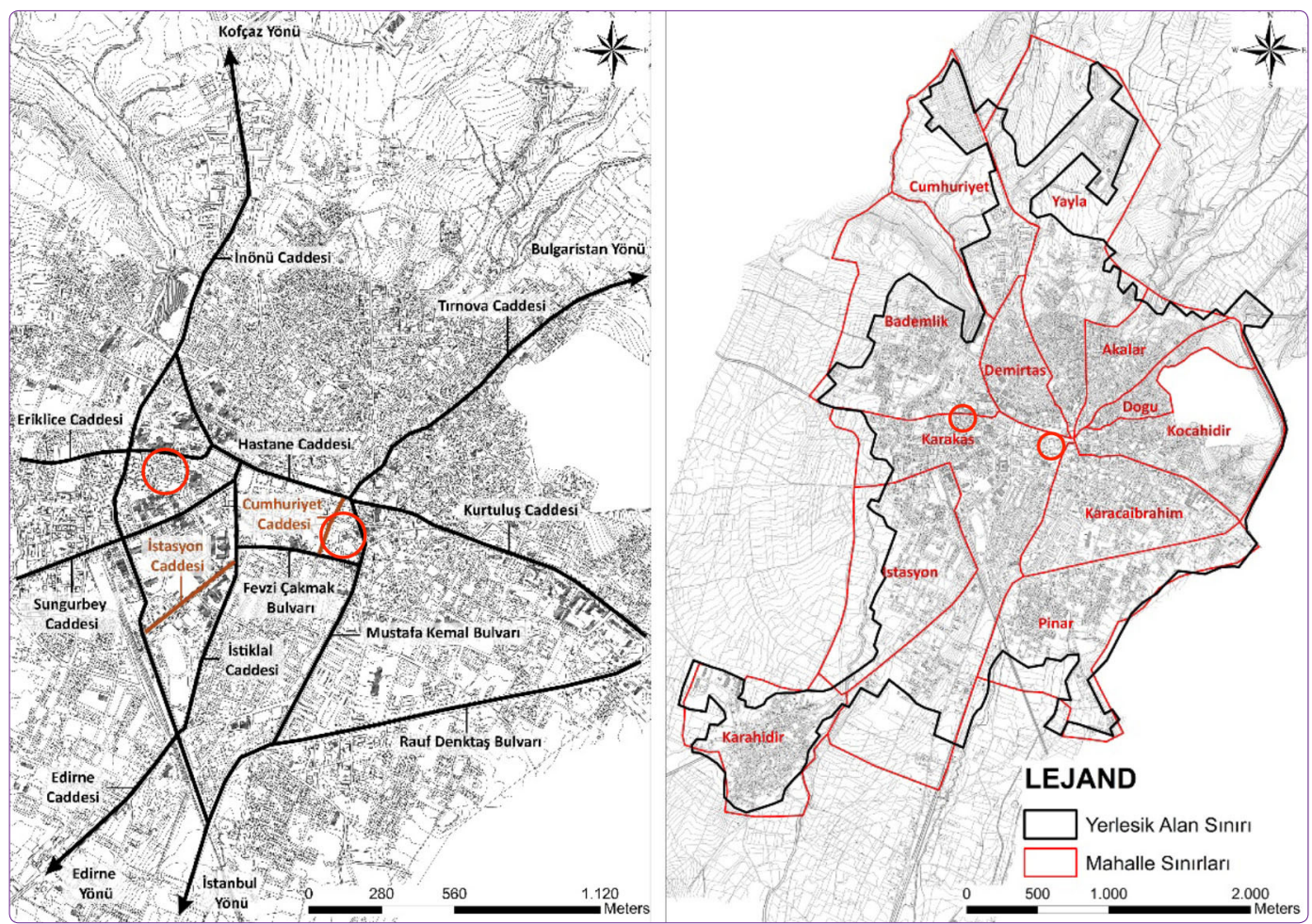

Şekil 4. Kent merkezi önemli akslar ve mahalle sınırları içinde örneklem alanları.

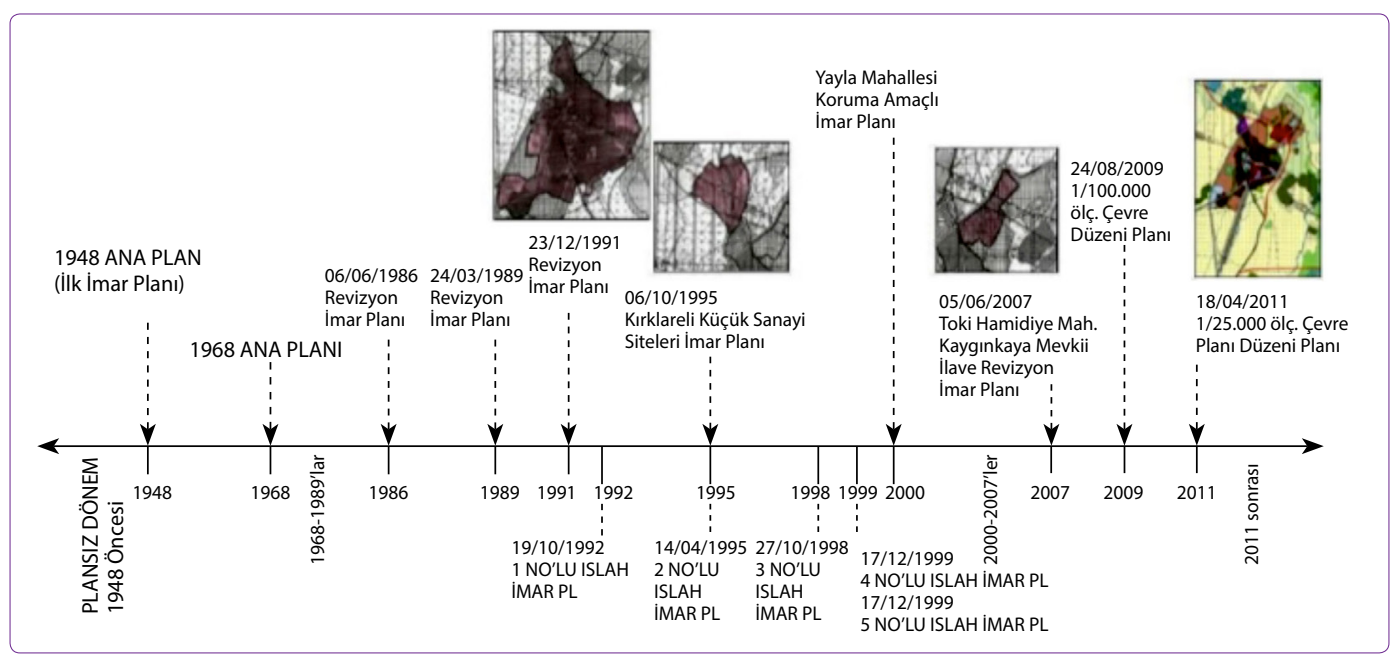

Şekil 5. Kırklareli kent merkezi planlama çalışmaları (Gündoğdu ve Altın 2015: 289).

rilmemiştir. Şekil 5'te planlama çalışmaları kronolojik sıra içinde verilmektedir.

Kırklareli kent merkezinin mevcut yapılaşma dokusu özelliklerine bakıldığında; mer'i planın yapılaşma şartlarının birçok bölgede henüz uygulanmadığı; kent merkezi ve kent merkezi yakın çevresinde ise plan kararlarına aykırı kat yüksekliklerine ve taban alan oturumlarına sahip yapılaşmalar olduğu gözlenmektedir. Bu kontrolsüz mekânsal gelişimle birlikte, kat yüksekliği ve yapı düzeni değişikliği ile yoğunluk arttrıcı veya donat alanlarını azaltıcı nitelikte yasal olarak yapılan parsel bazında plan değişiklikleri de bulunmaktadır.
Parsel bazında konut ve konut çevresini etkileyen plan değişiklikleri bazlı tipolojik gelişim kentin mekânsal formunu değiştirmekte, iklimsel şartlar ve çevresel özellikler bağlamında konut ve konut çevresi mekân kalitesini olumsuz yönde etkilemektedir. Şekil 6 ve 7'deki kesitlerde mekânsal yapılaşmadaki değişim görülmektedir. Değişimde dikkat çeken mevcut plan kararlarının (yükseklik, yapı düzeni ve taban oturumu açısından) tadilat talebine kadar hiç uygulanmamış olduğu, yerine taban oturumları, kat yüksekliklerinin artş̧ı şeklinde bir değişim ve düzenleme yapılarak uygulanmış olduğudur.

1995-2000 yılları arasında yapılan plan değişiklikle- 


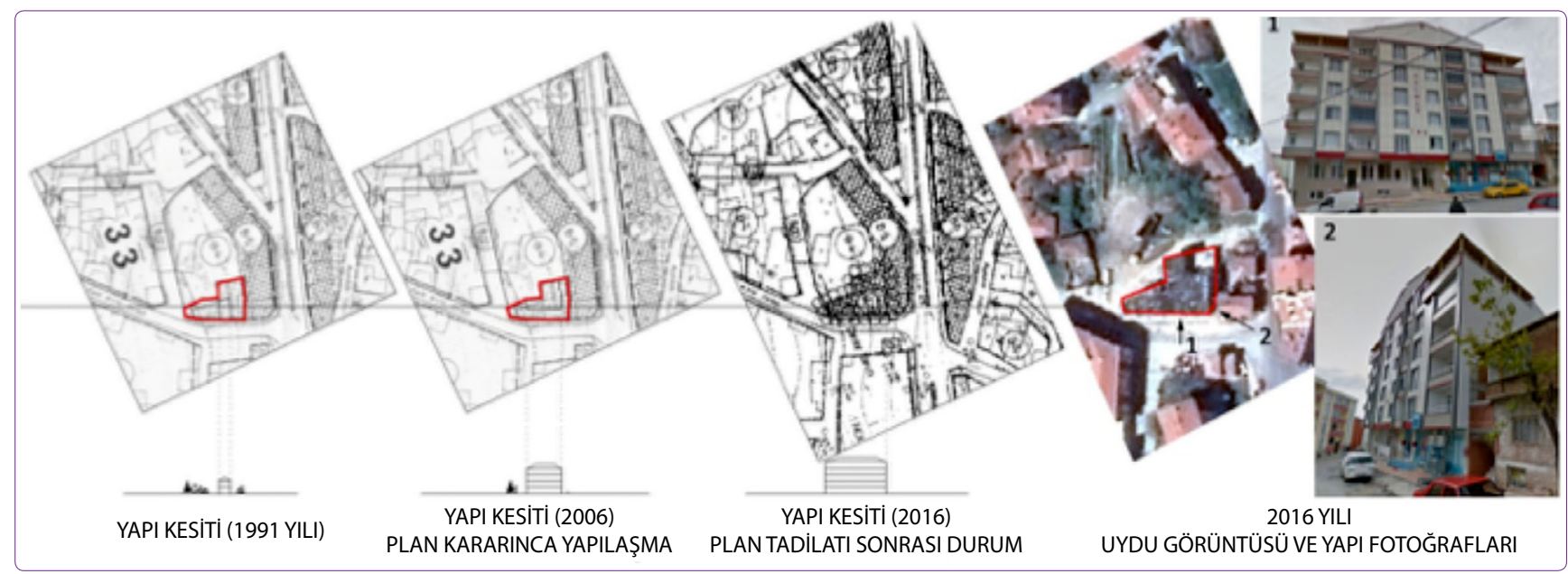

Şekil 6. Mekânsal yapılaşmadaki değişim (Gündoğdu ve Altın, 2015: 293).

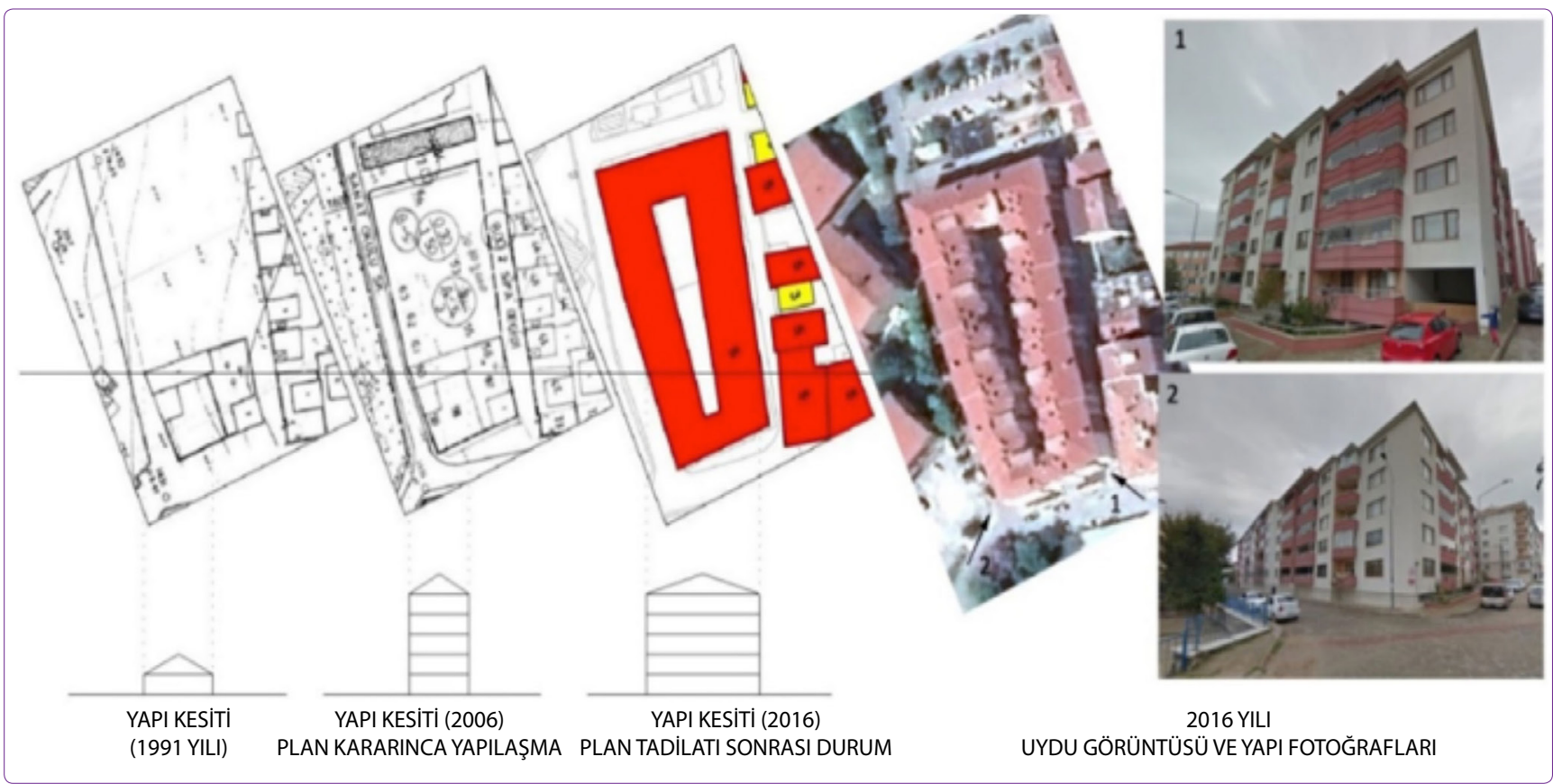

Şekil 7. Plan tadilatlarının yarattığı yapılaşma durumu (Özkök, 2016).

rinden \%10'unun, 2010-2015 arasında yapılan plan değişikliklerinden $\% 18^{\prime}$ inin bu niteliklerde olduğu ve plan tadilatlarının kentin ana aksları çevresinde kent merkezinde yoğunlaştı̆ı görülmüştür. Bu veriler doğrultusunda, mekânsal analizlerin ve anket çalışmasının yapılacağı örneklem bölgeler Karacaibrahim ve Karakaş kent merkezini kapsayan mahallelerden seçilmiştir (Şekil 8).

Örneklem bölgeler seçilirken kentin yaygın yapılaşma dokusunu temsil etmesi, kentsel dokuya ilişkin sorunların algılanabilmesi, farklı işlevsel özellik, farklı yapılanma şartları ve farklı yapı düzenlerinin bulunması göz önüne alınmıştir. Karacaibrahim Mahallesi'nde seçilen A örneklem bölgesi bitişik düzen yapılanma özelliklerinde ticaret ağırIıklı ticaret+konut bölgesi, Karakaş Mahallesi'nde seçilen B örneklem bölgesi ise bitişik ve blok nizam yapılanma özelliklerinde konut yoğunluklu ticaret+konut bölgesi olarak belirlenmiştir (Şekil 9).

Yapılaşma Özellikleri

İki bölgenin ortak özelliği, kent bütünü TAKS/KAKS oranlarına göre yüksek nüfus ve yapı yoğunluğuna sahip olmasıdır (Tablo 2).

A örneklem bölgesi güneyde Fevzi Çakmak Bulvarı, batıda Cumhuriyet Caddesi ve doğuda Mustafa Kemal Bulvarı Sokak ile sınırlı bölgeyi kapsamaktadır. A Bölgesi merkezi çekirdeğin içinde ve kentin ana ulaşım akslarının kesiştiği alanda bulunmaktadır. 1991 onanlı revizyon uygulama imar planı kararlarına göre; alanda farklı imar adalarında B-4, B-5, B-6, B-7 lejantlı, bitişik nizam, 4-5-6-7 kat yapı- 


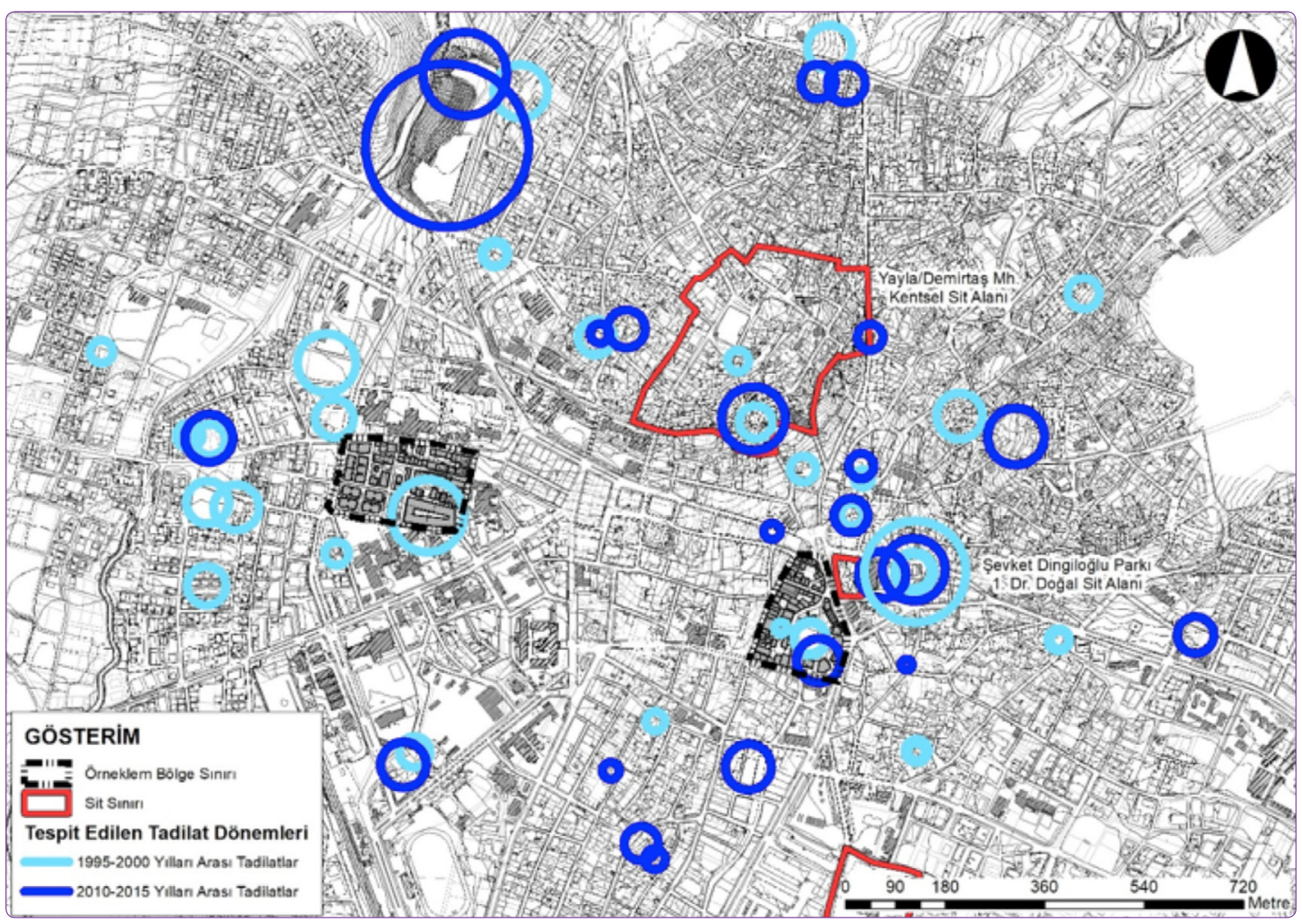

Şekil 8. Seçilen örneklem bölgeler ve yapılan imar planı tadilatlarının sınırları.
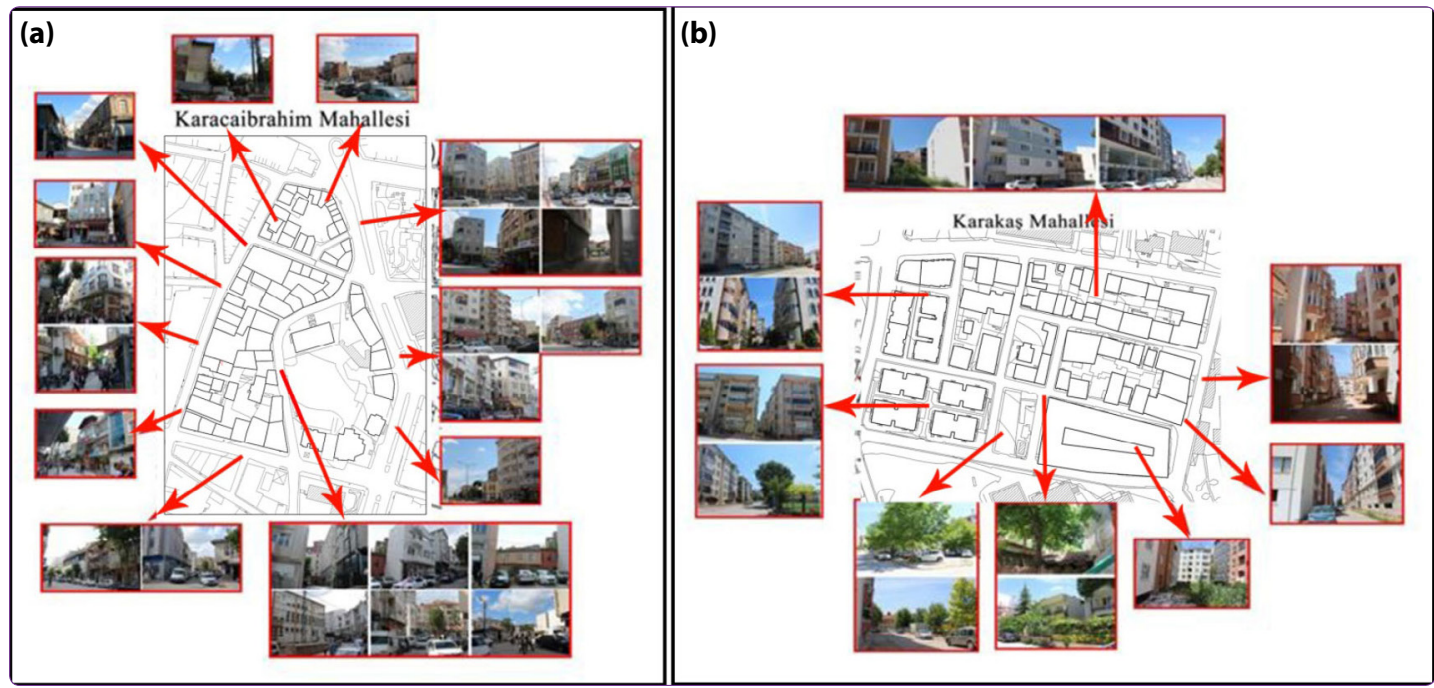

Şekil 9. (a) Örneklem bölge (Karacaibrahim Mah.) ve (b) örneklem bölge (Karakaş Mah.).

lanma kararı ve tüm adalarda ticaret işlevi özgülendiği izlenmektedir. Ana ulaşım akslarına bakan cephelerde genel olarak bitişik düzen 6 kat yapılanma hakkı verilirken, diğer ulaşım akslarına cepheli parsellerde bitişik düzen 4 veya 5 kat yapılanma hakkı verildiği görülmektedir (Şekil 10).

Güncel hâlihazır veriler ve 1991 yılı onanlı 1/1000 ölçekli revizyon uygulama imar planı kararları birlikte değerlendirildiğinde; plana uyumsuz yasadışı gelişimin görüldüğü tespit edilmiştir. Buna göre, U1 olarak gösterilen yapı adasın- da imar planı kararı bitişik nizam, beş kat olmasına rağmen 6 katlı yapılaşmaların olduğu görülmektedir. Bu bakımdan U1 olarak gösterilen adada yasal olmayan yapılaşma söz konusudur. U2 olarak gösterilen adada ise plan kararınca park ve otopark donatıları getirilmişken, günümüzde alanda sadece otopark alanı olarak kullanıldığı, yeşil alan donatısının gerçekleşmediği görülmektedir. Bu bakımdan alt bölgede imar planı ile getirilen sosyal donatıların oluşturulamadığı görülmektedir. 
Tablo 2. A ve B Örneklem Bölgeleri Ortalama TAKS/KAKS Değerleri

\begin{tabular}{lcccccc}
\hline & Ort. Yapı Taban Alanı & Ort. Kat Yüksekliği & Ort. Yapı Kat Alanı & Ort. Parsel Büyüklüğü & TAKS & KAKS \\
\hline A Bölgesi & 148 & 3 & 515 & 154 & 0.96 \\
B Bölgesi & 347 & 4 & 1637 & 4.34 \\
Merkez İlçe Geneli & 140 & 3 & 420 & 715 & 0.72 & 3.38 \\
\hline
\end{tabular}

Not:Yapı Taban Alanı, Yapı Kat Alanı ve Parsel Büyüklüğü için değerler metrekare cinsinden verilmiştir. Not(2): Eğer bir yapı iki veya daha fazla parsel üzerine oturuyorsa tevhid varmış gibi hesaplama yapılmıştır.

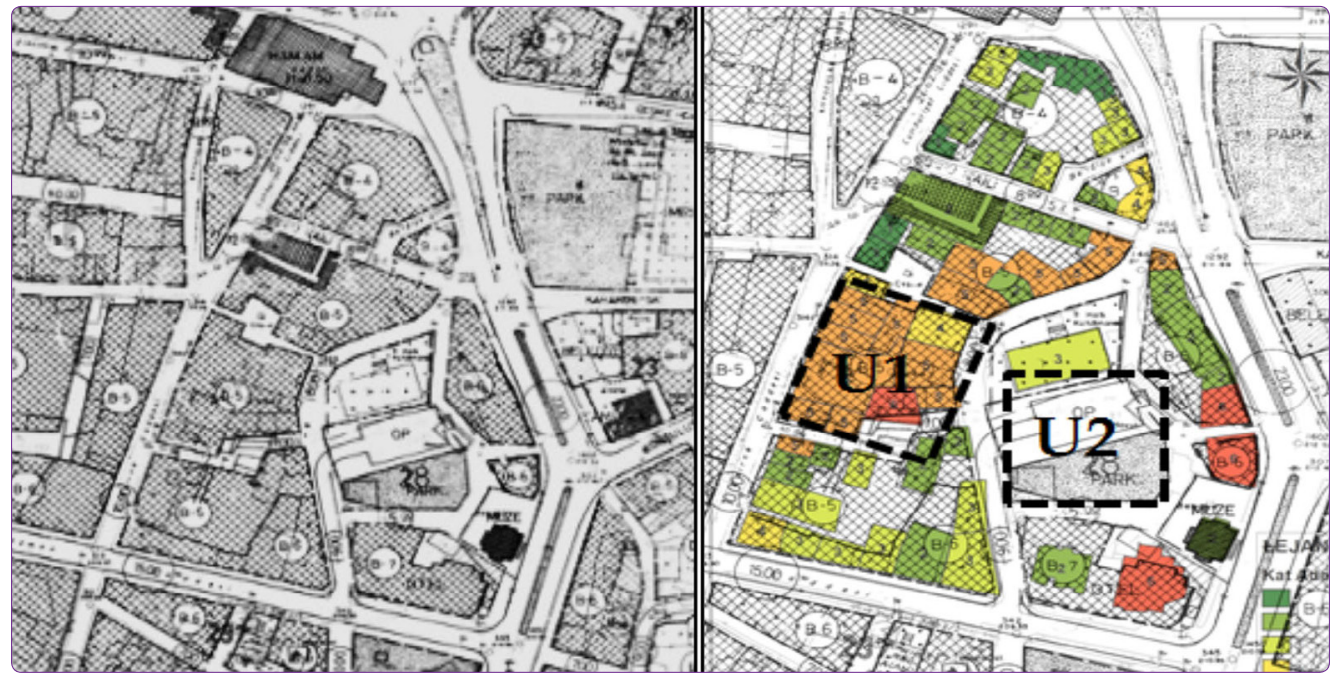

Şekil 10. A örneklem bölge plana uyumsuz gelişim gösteren adalar.

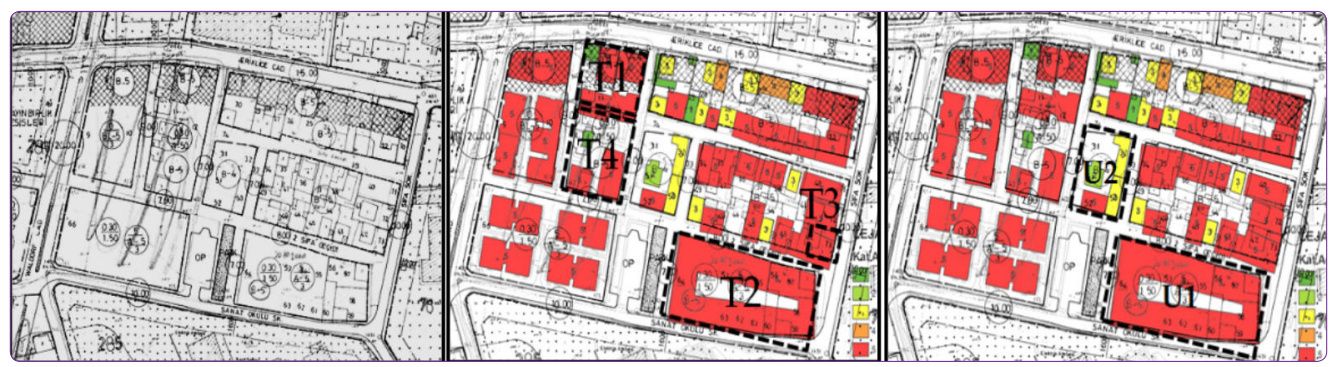

Şekil 11. B örneklem bölge tadilat yapılan ve plan kararlarına aykırı yapı adaları

B örneklem bölgesi Kuzeyde Eriklice Caddesi, güneyde Sanat Okulu Arkası Sokak, batida Waldorf Caddesi ve doğuda 1.Şifa Geçidi Sokak ile sınırlı bölgeyi kapsamaktadır. 1991 onanlı revizyon uygulama imar planı kararlarına göre; B örneklem bölgesi için; ana ulaşım akslarından biri olan Eriklice Caddesi cepheli parsellerde bitişik nizam 5 kat yapılaşma hakkı ve ticaret+konut (konut alt ticaret) işlevi verildiği diğer adalarda blok, ayrık ve bitişik düzen yapılaşma kararları ile konut kullanımı getirildiği ve kat yüksekliklerinin 4-5 kat arasında değiştiği, bölge içinde birbirinden farklı ve tutarlı olmayan yapı düzeni ve kat yüksekliği kararları getirildiği görülmüştür (Şekil 11). Bölgede yapılan tadilatlar incelendiğinde ise; 1999 onanlı tadilat kararı ile beraber (T1)'de görülen konut altı ticaret alanı derinliğinin büyütüldüğü;
2000 onanlı tadilat kararı ile beraber planda önerilen ayrık düzen, 5 kat yapılaşma kararının bitişik düzen 5 kat şeklinde değiştirildiği (T4) görülmektedir. İki tadilat da bölgede fonksiyonel ve yapılanma düzeni ile ilgili değişikliklere neden olmuştur. Ayrıca T2 olarak gösterilen adada da tadilat yolu ile plan kararlarından farklı olarak blok yapı düzeni getirildiği, U2 olarak gösterilen adada ise plan kararı bitişik düzen, dört kat olmasına rağmen 5 katlı yapılaşmanın gerçekleştiği görülmektedir. Bu bakımdan imar planına ve imar tüzesine uygun olmayan yapılaşmaların gerçekleştiği izlenmektedir.

\section{Bulgular}

Bu bölümde çalışma kapsamında yapılan analiz ve anket sonuçlarına ilişkin bulgular aktarılacaktır. 


\section{Yapılı Çevre Analizleri}

İlgili alt bölümlerde örneklem bölgelerde yapılı çevreyi tanımlamaya yönelik; arazi kullanımı, kat yüksekliği, doluluk-boşluk, TAKS/KAKS, gölgelenme, hava sirkülasyonu analiz sonuçları ile mer'i plana uygunluk değerlendirmesi aktarılacaktir.

\section{Arazi Kullanımı Analizi}

Seçilen örneklem bölgelerin arazi kullanım özellikleri incelendiğinde, A örneklem bölgesinde baskın kullanım karakterinin ticaret olduğu, bunun yanında çevresinde Be- lediye, Kütüphane, Adliye gibi kamu yapılarının olduğu, ticaret ve resmi kurumlara erişilebilirlik mesafesinde bulundukları tespit edilmiştir. B örneklem bölgesinin ise konut kullanımın yoğun olduğu ve çevresinde Devlet Hastanesi, Sağlık Ocağı, Fen Lisesi, Meslek Lisesinin yer aldığı ve erişilebilirlik mesafelerinde bulundukları, ticaret alanları gibi bölgedeki akışı çeken kamu işlevleri ve ekonomik faaliyetlerin bulunduğu tespit edilmiştir. A örneklem bölgesinde üst kat kullanımlarında konut işlevi daha az görülürken $B$ örneklem bölgesinde üst katlar tamamen konut kullanımındadır (Şekil 12-15).

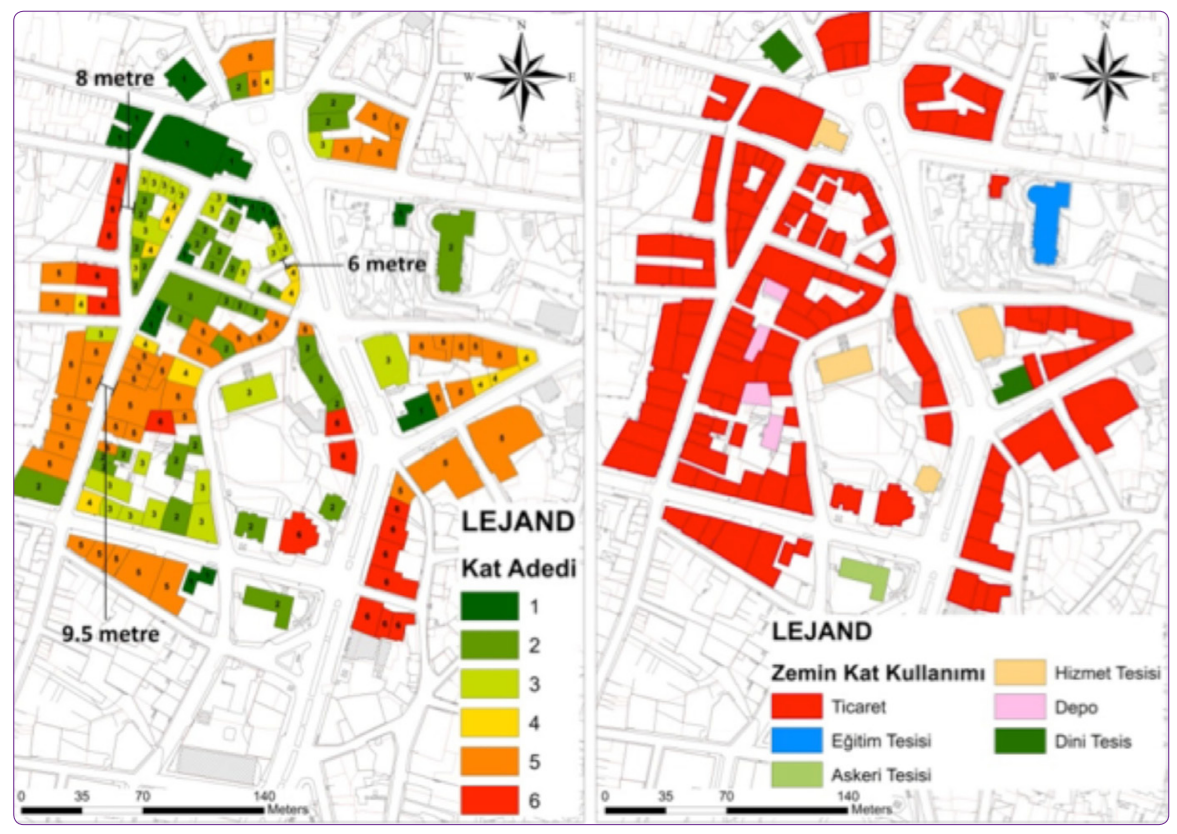

Şekil 12. A bölgesi ve yakın çevresi kat adedi, zemin kat kullanımı.

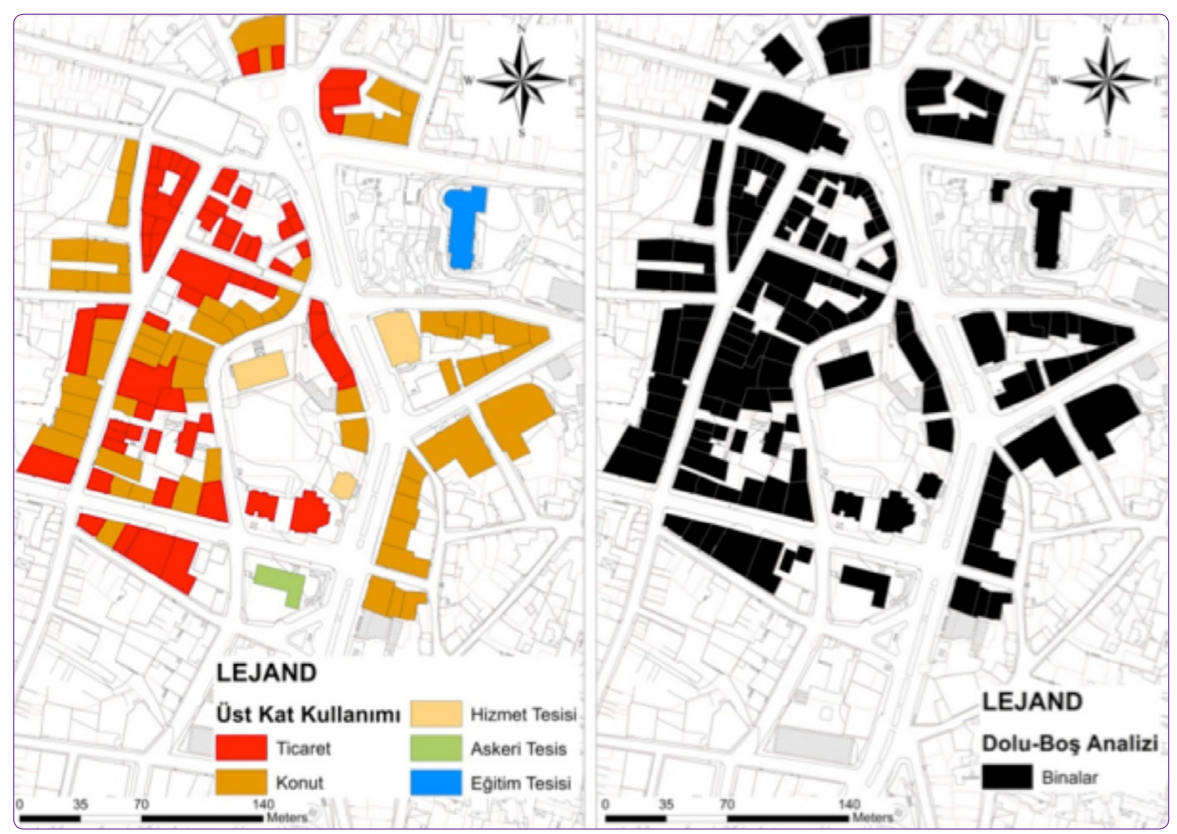

Şekil 13. A bölgesi ve yakın çevresi üst kat kullanımı ve doluluk-boşluk analizi. 


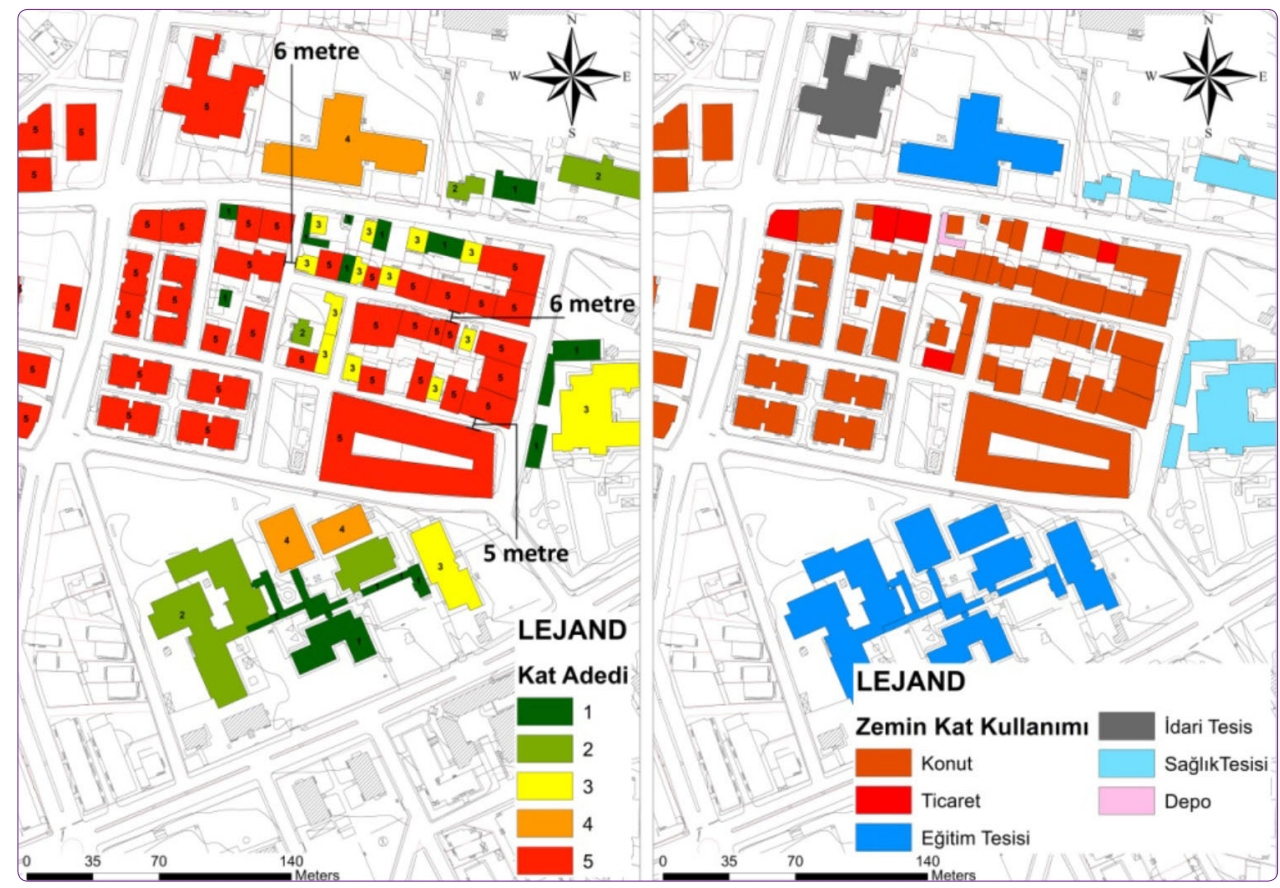

Şekil 14. B bölgesi kat adedi, zemin kat kullanımı.

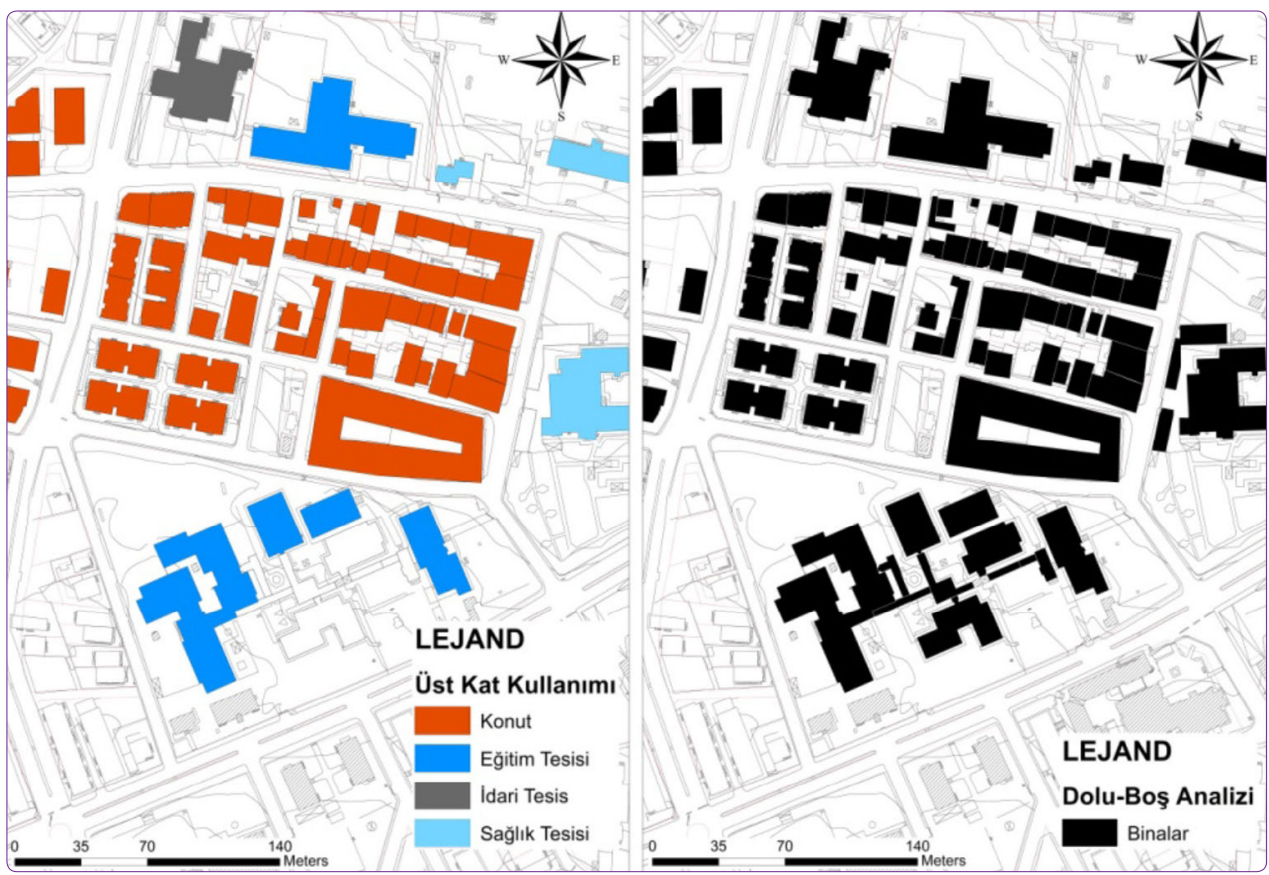

Şekil 15. B bölgesi üst kat kullanımı ve doluluk-boşluk analizi.

\section{Kat Yüksekliği Analizi}

A örneklem bölgesinde en düşük 1 katlı en yüksek 6 katlı yapılar bulunmaktadır. Düşük katlı yapılar çalışma alanının kuzey kesiminde yoğunlaşmaktadır. Bu bölge kentin merkez bölgesi içerisinde yer almaktadır. Bölgede bulunan düşük katlı yapıların zaman içerisinde yüksek katlı yapılara dönüştüğü ve dönüşmekte olduğu tespit edilmiştir. A örneklem bölgesi yapı kat yüksekliği yol genişlikleri oranlarına göre değerlendirildiğinde (Planlı Alanlar İmar Yönetme- liği, 2017), 3 ila 6 katlı yapılar arasındaki yol genişliklerinin olması gerekenden dar olduğu ve yapıların birbirlerine yakın olarak konumlandığı tespit edilmiştir (Şekil 12,14).

B örneklem bölgesinde ortalama kat yüksekliği 5 kat olarak görülmektedir. Bununla beraber çalışma alanında 1, 2 ve 3 katlı binalara da rastlanmıştır. Alanın kuzey kesiminde 1,2 ve 3 , güney kesiminde 2 ve 3 , orta kısmında ise 4 ve 5 katlı yapıların yoğunlaşttğı görülmektedir. Alanın doğusunda bulunan ana ulaşım bağlantısı çevresinde 6 katlı yapı- 


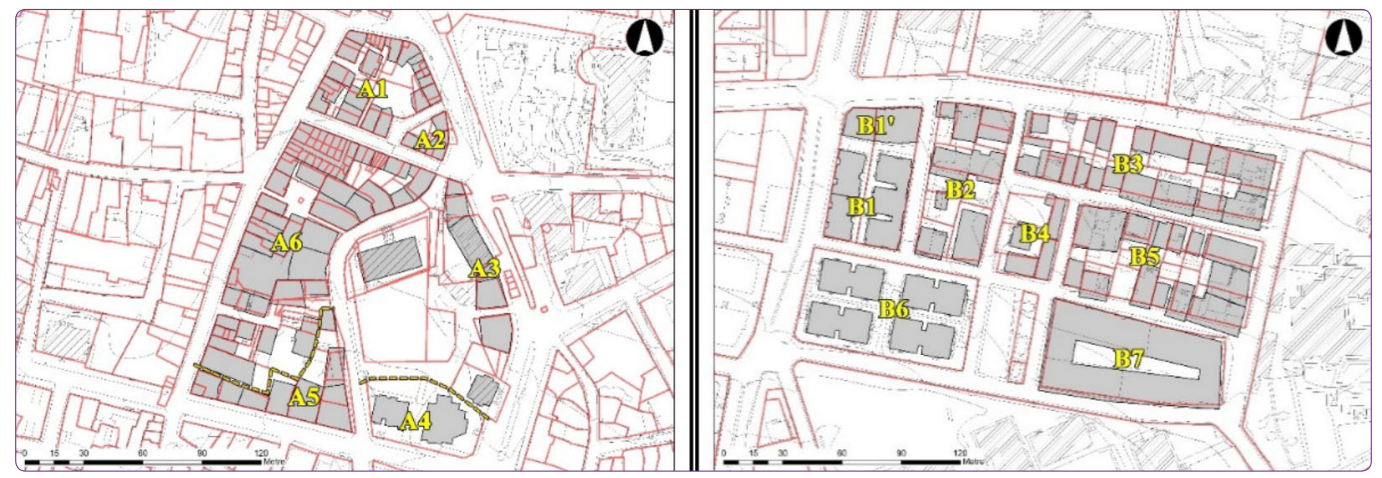

Şekil 16. A ve B bölgesinde TAKS/KAKS analizi yapılan adalar (Atlık Harita: 2015 yılı güncellenmiş halihazır).

lar bulunmaktadır. B örneklem bölgesi yapı kat yüksekliği yol genişlikleri oranlarına göre değerlendirildiğinde (Planlı Alanlar İmar Yönetmeliği,2017), yol genişliklerinin olması gerekenin çok altında olduğu, yapıların birbirine çok yakın olarak konumlandığı tespit edilmiştir (Şekil 12,14).

\section{Doluluk-Boşluk Analizi}

A örneklem bölgesi doluluk-boşluk analizi incelendiğinde, bina taban alanlarının parselin büyük çoğunluğunu kapladığı, çoğu yerde de parselin tamamının bina taban alanı olarak kullanıldığı görülmektedir Ticaret kullanımının getirdiği bu yapılaşma düzeni kütüphane, müze, otel gibi kullanımlarda farklıık arz etmekte ve nispeten daha az yoğun yapılaşma dokusu getirmektedir. Bununla beraber çalışma alanının kuzey-güney orta aksında yer alan mer'i planda otopark alanı ve park alanı olarak ayrılmış alan çalışma alanındaki en büyük açıklığı oluşturmaktadır. Kat adetleri ile birlikte doluluk-boşluk analizi değerlendirildiğinde düşük katlı binaların genellikle daha düşük taban alanına sahip olduğu saptanmıştr. B örneklem bölgesinde ise yapıların taban oturumlarının parselin tamamını kaplamamasına rağmen yoğun bir yapılaşma söz konusudur (Şekil 13, 15). Doluluk-boşluk oranlarına ilişkin sayısal veriler TAKS/KAKS analizi bölümünde verilmiştir.

\section{TAKS/KAKS Analizi}

$A$ ve $B$ örneklem bölgeleri için taban alanı kat sayısı (TAKS) ve kat alanı kat sayısı (KAKS) değerlerine ilişkin yapılmış analiz sonuçlarına göre, yapılaşmanın ilgili bölgelerde kent geneline göre çok yüksek değerlerde olduğu kimi adalar için mer'i imar plan kararlarına aykırı değerler taşıdığı görülmüştür (Şekil 16, Tablo 3). Bunda en büyük etki, bu alanların rantın en yüksek olduğu kent merkezine yakın alanlar olması, ve bu nedenle oluşan yapılaşma baskısıdır.

A örneklem bölgesinde imar plan kararları adalar bütününde bitişik nizam olması ve mevcut yönetmeliklerimizde bitişik nizam yapılaşma biçimi için taban alanı kat sayısı sınırının getirilmemesinden ötürü; en yüksek 0.97 , en düşük

Tablo 3. A ve B Bölgelerinde Belirlenen Adaların TAKS/KAKS Değerleri ve Mevcut İmar Plan Kararları Karşılaştırması

\begin{tabular}{|c|c|c|c|c|c|}
\hline \multirow[t]{2}{*}{ Bölge } & \multirow[t]{2}{*}{ Ada } & \multirow{2}{*}{$\begin{array}{c}\text { Plan Kararları (1991) } \\
\text { 1/1000 ölçekli Uygulama İmar Plan Kararı }\end{array}$} & \multicolumn{3}{|c|}{ Mevcut Durum (2015) } \\
\hline & & & En Yüksek Kat & TAKS & KAKS \\
\hline$A$ & $\mathrm{~A} 1$ & Bitişik Nizam- 4 Kat / Ticaret + Konut & 3 & 0.85 & 1.77 \\
\hline$A$ & $\mathrm{~A} 2$ & Bitişik Nizam- 4 Kat / Ticaret + Konut & 4 & 0.97 & 3.28 \\
\hline A & A3 & Bitişik Nizam- 6 Kat / Ticaret + Konut & 6 & 0.56 & 1.8 \\
\hline$A$ & A4 & Bitişik Nizam- 7 Kat / Ticaret + Konut & 6 & 0.37 & 1.68 \\
\hline A & A5 & Bitişik Nizam- 6 Kat / Ticaret + Konut & 4 & 0.92 & 3.52 \\
\hline A & A6 & Bitişik Nizam- 5 Kat / Ticaret + Konut & 6 & 0.94 & 2.67 \\
\hline B & B1 & Blok Nizam- 5 Kat / Ön Bahçe:0, Yan Bahçe:3 / TAKS-KAKS Yok & 5 & 0.84 & 4.22 \\
\hline B & $\mathrm{B} 1^{\prime}$ & Bitişik Nizam- 5 Kat / Konut Altı Ticaret & 5 & & \\
\hline B & B2 & Bitişik Nizam- 5 Kat / Konut Altı Ticaret / TAKS: 0.30 - KAKS: 1.50 & 5 & 0.63 & 3.21 \\
\hline B & B3 & Bitişik Nizam- 5 Kat / Konut Altı Ticaret & 5 & 0.75 & 3.05 \\
\hline B & B4 & Bitişik Nizam- 4 Kat & 5 & 0.70 & 2.5 \\
\hline B & B5 & Bitişik Nizam- 5 Kat & 5 & 0.72 & 3.36 \\
\hline B & B6 & Ayrık Nizam- 5 Kat / Ön Bahçe:5, Yan Bahçe:3 / TAKS: 0.30 - KAKS: 1.50 & 5 & 0.47 & 2.35 \\
\hline B & B7 & $\begin{array}{l}\text { Ayrık Nizam- } 5 \text { Kat / Ön Bahçe:5, Yan Bahçe:3 / TAKS: } 0.30 \text { - } \\
\text { KAKS: } 1.50 \text { // 20.10.2000 yılı Plan Tadilatı ile Bitişik Nizam - } 5 \text { Kat Değişikliğii }\end{array}$ & 5 & 0.88 & 4.42 \\
\hline
\end{tabular}


0.37 olacak şekilde TAKS değerleri tespit edilmiştir. A3 ve A4 adaları haricinde, A bölgesi TAKS ve KAKS değerlerinin çok yüksek olduğu görülmektedir. Yaklaşık olarak parselin tüm alanını kullanan bir yapılaşma biçiminin gerekli havalanma ve güneşlenme işlevlerini ve konforlu bir yaşam ortamını sağlaması mümkün değildir. Ayrıca $\mathrm{A}$ bölgesinde bulunan $\mathrm{A} 6$ adasında, mer'i imar plan kararlarına aykırı daha yüksek katlı yapıların olduğu tespit edilmiştir. B bölgesinde ise, A bölgesindeki söyleme benzer olarak bitişik düzen yapılaşma hakkı verilen adalarda en yüksek 0.84 , en düşük 0.70 şeklinde TAKS değerleri tespit edilmiştir. B bölgesindeki ayrık nizam kararlı bölgelerde de imar planına aykırı olarak TAKS ve KAKS değerlerinin çok üstünde yapılaşmaların olduğu görülmektedir.

A ve $B$ bölgeleri için nicel olarak tespit edilmiş ve gözlemlerle de desteklenen bu durum; bölgede yapılaşma kontrolü açısından denetimlerin eksik olduğunu gösterdiği gibi bölge ve çevresinde konum itibari ile gelen yoğun yapılaşma taleplerinin plan kararlarının çok üstünde bir yapılaşma oluşmasına neden olduğunu da göstermektedir.

\section{Gölgelenme ve Hava Sirkülasyonu Analizi}

$A$ ve $B$ bölgelerine yönelik gölgelenme analizini yapmak için; (Mississagua 2014:8-9) kaynağında belirtilen standart gün ve saat değerleri kullanılmıştir. Sketch Up Pro 2017 programında $A$ ve $B$ çalışma bölgelerinin üç boyutlu modelleri hazırlanmış ve Kırklareli kent merkezi koordinatın- da, UTC +3.00 zaman diliminde, belirlenen saat ve tarihlerde (Tablo 1) simülasyonlar uygulanmıştır (Şekil 17).

$A$ ve $B$ bölgeleri için gölgelenme analiz sonucunda ortak bir çıkarım olarak yılın belirlenen tüm gün ve saat değerleri için alanın büyük bir kısmının gölgede kaldığı, özellikle akşam saatlerindeki gölge boylarının çok uzun olduğu ve güneşlenme oranının çok düşük olduğu tespit edilmiştir. Bunun temel nedenleri ise, bölgedeki ve çevresindeki yapıların kat yüksekliklerinin ve aynı şekilde taban kat alanlarının kent merkez geneline oranla yüksek değerlerde olmasıdır. Bu nedenlerden ötürü simüle edilen tüm gün ve saatlerde yapıların genellikle sadece en üst katlarının güneşlenmeden tam olarak faydalanabildiği görülmüştür.

Hava sirkülasyonu analizi içinse öncelikli olarak Kırklareli kent merkezinin rüzgâr hızı ve yön değerlerine ilişkin inceleme yapılmıştr. Kırklareli kent merkezinin hâkim rüzgâr yönü kuzey ve kuzeydoğu yönleri olup, ortalama hızı ise 6 $\mathrm{km} / \mathrm{s}$ değerindedir (Trakyaka, 2012:45-50). Ancak son dönemlere dair (Kasım 2018-Aralık 2018 arası) yapılan rüzgâr hızı değerlerine yönelik incelemede hâkim rüzgâr yönü yine kuzey ve kuzeydoğu eksenli olmasına rağmen hızın kent içinde $1,5-2 \mathrm{~km} / \mathrm{s}$ değerlerine düştüğü görülmüştür (WO, 2018) (Şekil 18). Hava sirkülasyon analizi için, Sketch Up Pro 2017 programında A ve B bölgeleri için üç boyutlu modeller hazırlanmış, Autodesk Flow Design 2014 programında tanımlı olan sanal rüzgâr türbininde Kırklareli kent

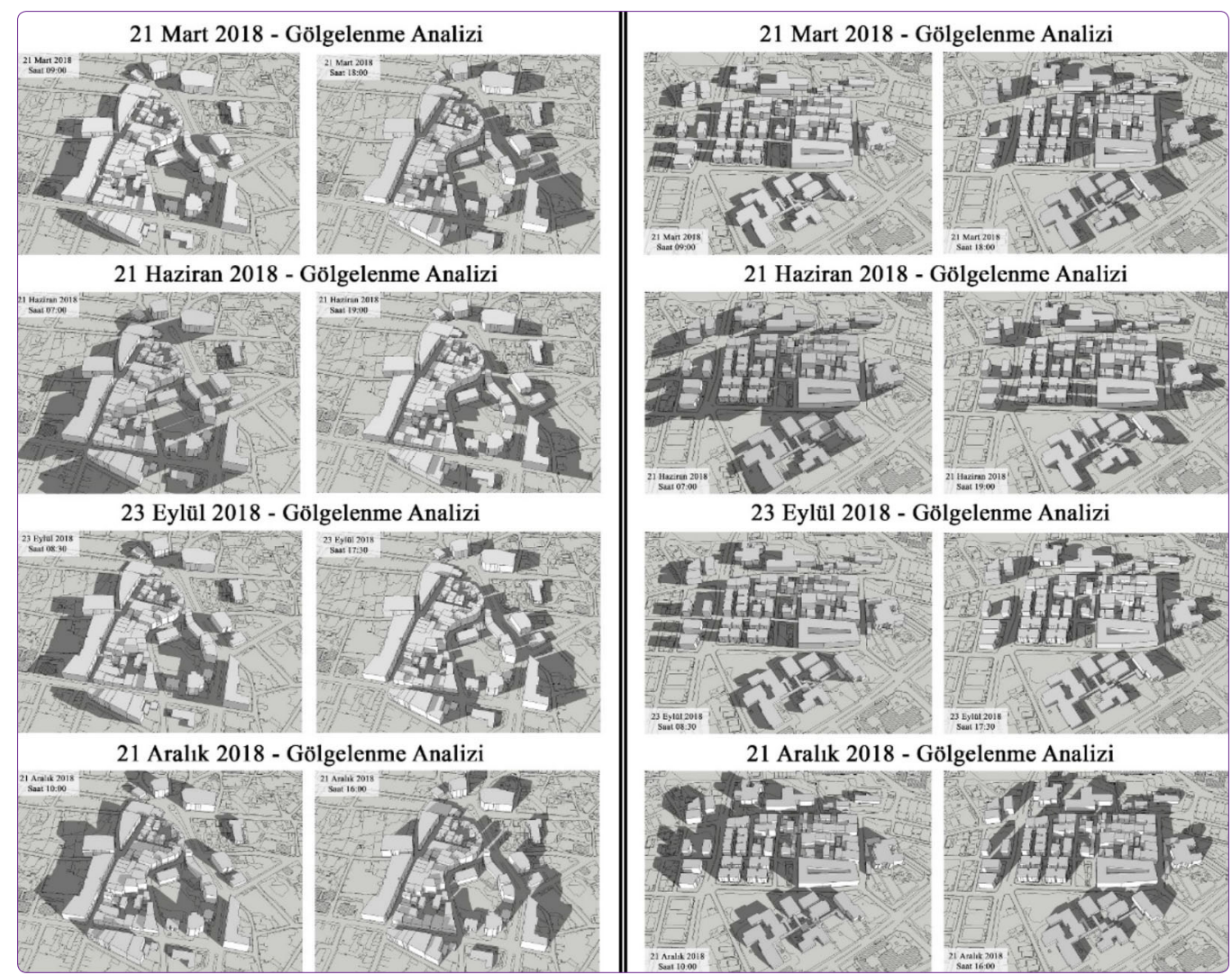

Şekil 17. A ve B bölgeleri gölgelenme analizi. 


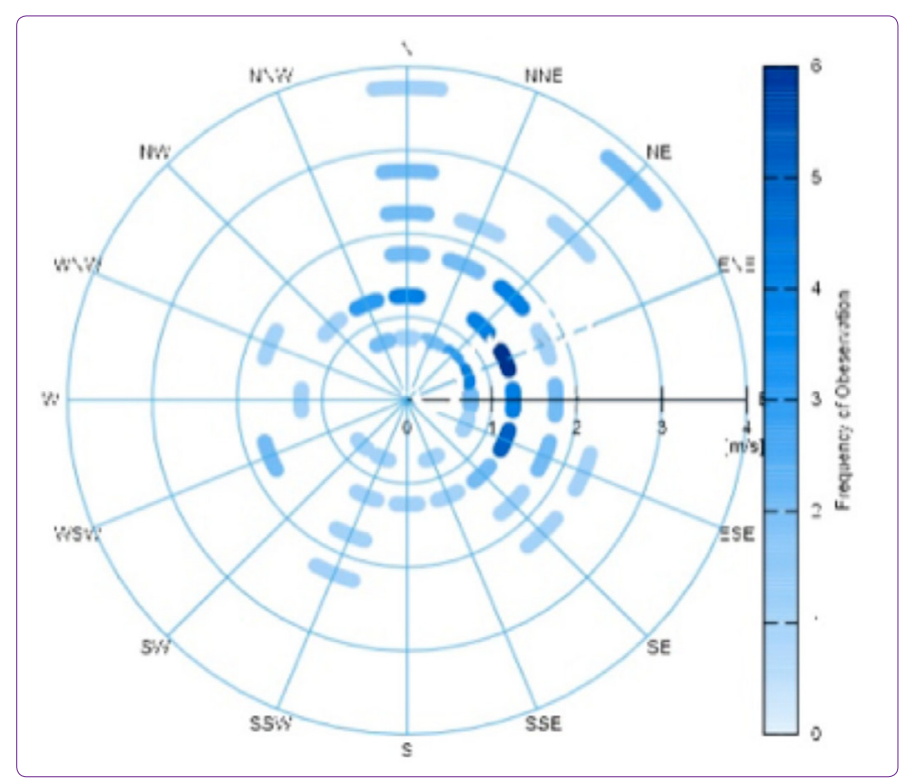

Şekil 18. Kırklareli kent merkezi 19.11.2018-17.12.2018 tarihleri arası rüzgâr yön ve hızı diyagramı (WO, 2018).

merkezi için son dönemler için elde edilen rüzgâr hızı ve rüzgâr yönleri için hava sirkülasyon simülasyonları uygulanmıştır (Şekil 19).

Simülasyon sonuçlarına göre $A$ ve $B$ bölgesi için ortak olarak ada içlerinde ve yapı gruplarının bulunduğu alanlarda hava sirkülasyonun çok düşük değerlerde olduğu ve düzenli bir akışın sağlanamadığı görülmektedir. İki bölge arasında bir kıyaslama yapıldığında A bölgesinde yapıların taban oturumları, bitişik yapı nizam düzenleri ve birbirlerine göre konumları nedeniyle hava sirkülasyonundan nerdeyse hiç faydalanılamadığı, B bölgesinde ise kuzey güney aksı üzerinde bulunan henüz mer'i plana uygun olarak yapılaşmamış olan ayrık nizam, bölgenin geneline göre daha az katlı yapılanma ve taban oturumlarının olduğu alanın kısmen hava akışına izin verdiği görülmektedir. Genel anlamda bu durumun oluş- masında temel nedenler, yapıların hâkim rüzgârı kesecek ve akışını sağlamayacak şekilde konumlanması, yüksek katlı ve geniş taban alanlı yapı tipolojisinin olması, yapılar arası boşlukların dar olması ve keskin bina köşelerinin bulunmasıdır. Dolayısı ile bölgelerin yapılaşma etkenleri sonucu oluşmuş dokusunun hava sirkülasyonu açısından kalitesiz bir ortam sunduğunu söylemek mümkündür.

\section{Kullanıcı Anket Sonuçları}

Anket sonuçları, kullanıcı bilgileri, konut bilgileri, konut memnuniyeti, konut çevresi memnuniyeti, kullanıcı tercih ve beklentileri başlıkları altında değerlendirilmiştir.

\section{Kullanıcı Bilgileri}

Gerçekleştirilen anket çalışmasında, her iki bölgede de kadın (A Bölgesi için \%56, B Bölgesi için \%60) ve $31-45$ yaş arası (A için \%33, B için \%34) katılımcılar daha fazla orandadır. Eğitim düzeyine bakıldığında lise ve yükseköğretim mezunları (A için \%44, B için 34) en yüksek orandadır, bunu ortaokul mezunları izlemektedir. Ev hanımı, öğrenci ve emekli olarak tespit edilen meslek gruplarına göre, her iki bölge için (A için \%40, B için \%37) ev hanımı çoğunluktadır. Gelir durumu (A için \%52, B için \%50) $1300-3000$ TL arası olarak en çok, hemen ardından (3000+) seçeneği oranı yüksek olarak beyan edilmiştir. Asgari ücret $B$ bölgesinde $\% 9$ 'luk bir orandadır. Evde 8 ya da daha fazla sayıda nüfus bulunan aile katilımcılar arasında yoktur. B bölgesinde 4 7 kişilik aileler çoğunluktayken, A bölgesinde 3 ve daha az kişilik aileler ile 4- 7 kişilik aileler oranı eşittir. Ev sahibi olarak ikamet eden katılımcılar iki bölgede de (A için \%87, B için \%78) çoğunluktadır. 7 - 12 yıldır ikamet edenler A bölgesinde $(\% 47,5)$ en fazla orandadır. B bölgesinde 6 yıl ve daha az süre ile (\%36) ikamet edenler en fazla orandadır.

\section{Konut Bilgileri}

Bina yaşları, her iki bölgede de en fazla oranda $11-30$ yaş arasındadır. B bölgesinde 11 yaşın altında binalar A
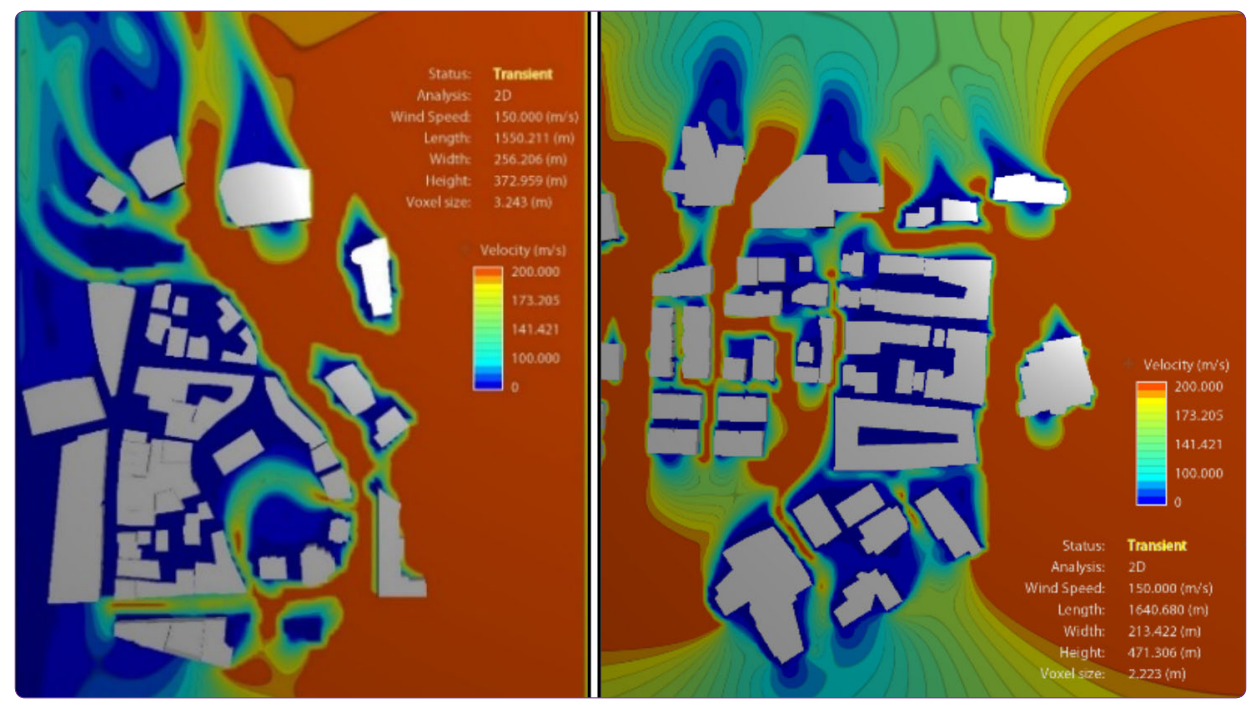

Şekil 19. A ve B bölgesi hava sirkülasyonu simülasyon görseli. 
bölgesinden daha fazladır. 80 metrekare ve daha küçük büyüklüğe sahip konutlar sadece B bölgesinde (\%4) vardır. 81-150 metrekare arası büyüklüğe sahip binalar, iki bölgede de çoğunluktadır. 2 ve daha az sayıda odası bulunan bina iki bölgede de yoktur. 3 odası bulunanlar A bölgede (\%55), 4 ve daha fazla odası bulunanlar ise B bölgesinde (\%77) yer alan evlerde bağımsız bölümlerde çoğunluktadır.

Her iki bölgede de, konutların salon-oturma odasının yönlenmesi çoğunlukla güney yönündedir (A için \%33, B için \%39), bunu bath yönü izlemektedir. Yatak odalarının yönlenmesinde ise, A bölgesinde çoğunlukla güney-güneybat yönünde (\%38), B bölgesinde daha çok bat-güneydoğu yönünde (\%44) konumlanma vardır. Her bölgede, katilımcıların çoğunluğu, evlerini satın alırken ya da kiralarken baktığı yöne dikkat etmiştir (A için \%82, B için \%79). Her iki bölge kullanıcıları (A için \%80, B için \%82) binaların konumlanmasının rüzgârı kestiğini, bununda evlerinin doğal havalandırmasına engel olduğunu dile getirmişlerdir. B bölgesinde evlerin geniş olmasını (\%61), A bölgesinde evlerindeki yaşam alanlarının genel olarak kullanışlı olduğunu (\%82) dile getirenler çoğunluktadır. Isıtma tiplerinde, kombi ve doğalgaz yakıt ile ısınma iki bölgede de çoğunlukta olan ısıtma tipidir. Kömür ve soba ile ısınma iki bölgede de kullanılmamaktadır. B bölgesinde, ortalama yakıt için harcanan miktar daha fazladır. Kışın, oturulan yerde ve çevre bölgede hava kirliliği olmadığını düşünenler iki bölgede de çoğunluktadır. Ancak $A$ bölgesinde $\% 30$ oranında, B bölgesinde ise $\% 8$ oranında hava kirliliği olduğunu düşünenler mevcuttur. $B$ bölgesinde, klima ve vantilatör kullanımı doğal havalandırmaya göre daha yüksek orandadır (\%65). A örneklem bölgesinde kullanılan soğutma çözümleri birbiri ile aynıdır. İki bölgede de yaz ve kış elektrik giderleri arasında fark vardır. B bölgesinin ortalama harcanan elektrik ödemeleri A bölgesine göre daha fazladır.

\section{Konut Memnuniyeti}

Konut memnuniyetinde (Hiç memnun değilim, Memnun değilim, Normal, Memnunum, Çok memnunum) seçe- nekli beşli likert ölçeğinde değerlendirme yapılmıştır. Her iki bölgede de konut memnuniyeti ile ilgili maddelerde kullanıcıların yüksek oranla konutlarından memnun oldukları tespit edilmiştir. Konut memnuniyetine ilişkin genel ortalama puan \%74'tür (Şekil 20). Kıyaslama için bu ortalamanın üstünde ve altında olarak değerlendirme yapılmıştır. Kullanıcıların, konut memnuniyeti ile ilgili var olan 10 madde içerisinde, en yüksek puanı "konum" olarak kullandıkları görülmüştür. Bu değerler A bölgesi için \%64 memnun, \%36 çok memnun, B bölgesi için \%82 memnun, \%15 çok memnundur. Ortalamanın üzerinde kalan maddeler; büyüklük, mekânların güneş ışığı alması, mekânların havalandırması, işlevsellik - kullanışlıık maddeleridir. B bölgesinde mekânların gün ışığı almasından \%2 oranında memnun olmayan çıkmıştır. A bölgesinde mekânların havalandırılması için \%3,4 B bölgesinde \%1,6 oranında memnun olmayan bulunmaktadır. Soğuğa karşı yalıtım, dış görünüm ve manzara maddeleri ise ortalamanın altında kalan memnuniyet maddeleridir. Manzaradan duyulan memnuniyet, en alt düzeyde olan memnuniyet maddesidir. Dış görünümde $A$ bölgesi için \%13, B bölgesi için \%7,3 oranında memnuniyetsizlik vardır. Manzara için iki bölgede de yaklaşık \%20 oranında memnuniyetsiz yanıtı alınmıştır (Şekil 20).

\section{Konut Çevresi Memnuniyeti}

Konut çevresi memnuniyetinde, kullanıcılardan binalar arası mesafe, sokak genişlikleri, mahremiyet, yeşil alan, çocuk oyun alanı, araç park yerleri varlığı, güvenlik, komşuluk, erişilebilirlik başıkları altında 18 maddenin 5'li likert ölçeğinde değerlendirilmesi istenmiştir. Her iki bölgede de konut çevresi memnuniyeti ile ilgili maddelerde kullanıcıların yüksek oranla konut çevrelerinden memnun oldukları tespit edilmiştir. Konut çevresinden memnuniyetin belirlendiği memnuniyet maddelerinin genel ortalaması yaklaşık \%75'tir (Şekil 21). "Merkeze yakınlık/erişebilirlik" bu maddeler içerisindeki en yüksek değere sahip olan maddedir. Bu değerler A için \%18 normal, \%49 memnun, \%32

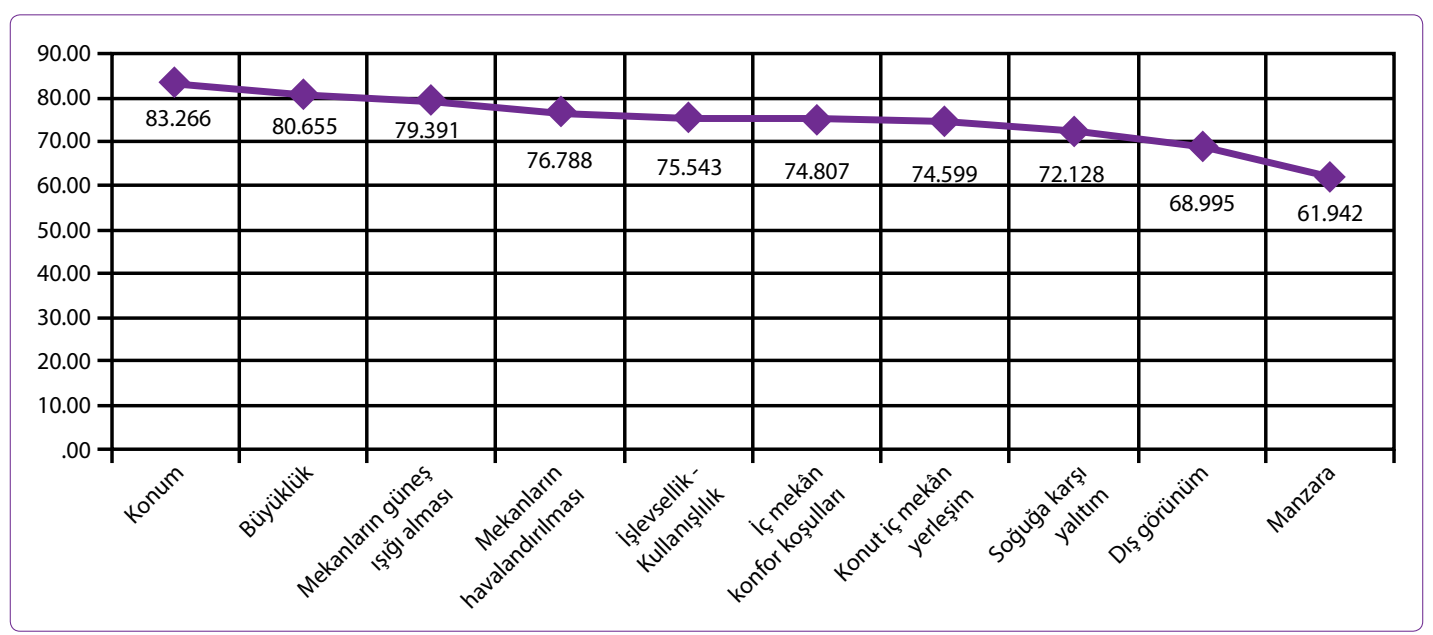

Şekil 20. Konut memnuniyeti ortalamaları. 


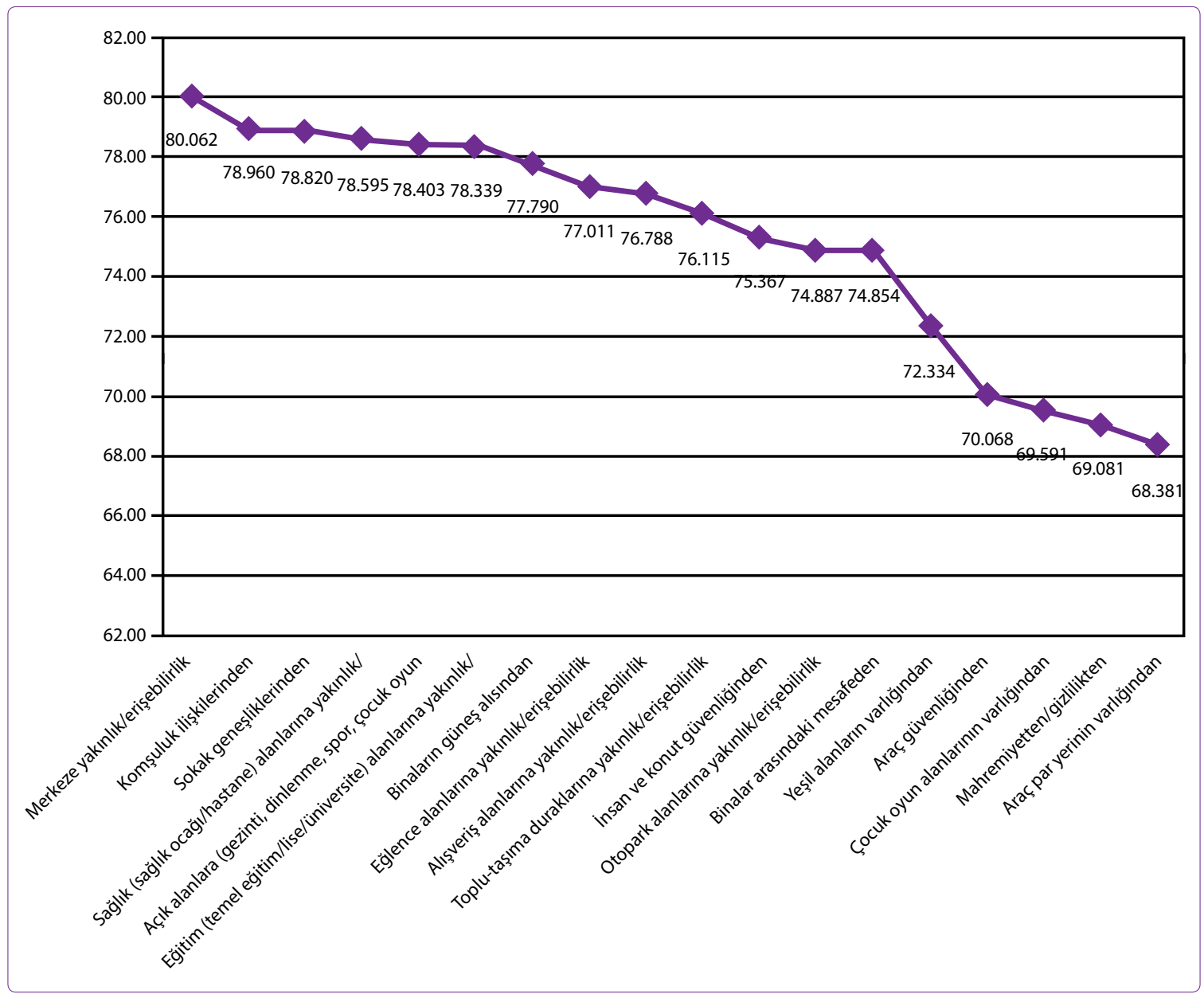

Şekil 20. Konut çevresi memnuniyeti ortalamaları.

çok memnun, B için \%16 normal, \%59 memnun, \%21 çok memnun oranındadır. Komşuluk ilişkileri, sokak genişlikleri, sağlık alanlarına, açık alanlara, eğitim alanlarına yakınIık/erişebilirlik, binaların çevre binaların konumu açısından güneşlenme durumu, eğlence alanlarına, alışveriş alanlarına toplu taşınma duraklarına yakınlık/erişebilirlik, insan ve konut güvenliği maddeleri, ortalama puanın üzerinde yer alan konut çevresi memnuniyet maddeleri olmuştur. Komşuluk ilişkilerinde A bölgesi \%5,7 oranında, B bölgesi $\% 1$ oranında memnuniyetsizlik, binaların güneş ışığı almasından B bölgesinde \%5,2 oranında memnuniyetsizlik bulunmaktadırlar. Otopark alanlarına yakınlık/erişilebilirlik, yeşil alanların varlığı, araç güvenliği, çocuk oyun alanlarının varlığı, mahremiyet/gizlilik ve araç park yerlerinin varlığı ise her iki bölgede de ortalama genel puandan düşük olan maddelerdir. B bölgesi için otopark alanlarına yakınlık/erişilebilirlik ve her iki bölge de binalar arası mesafe oranı hiç memnun olunmadığı belirtilen maddelerdir. B bölgesinde yeşil alan (\%10'a \%5), çocuk oyun alanı (\%12'ye \%7), araç güvenliği (\%11'e \%2) ve araç otoparkı varlığı (\%17'ye \%5) konularında $\mathrm{A}$ örneklem bölgeden daha yüksek memnuniyetsizlik durumu söz konusudur.

\section{Konut - Konut Çevresi Memnuniyetinde Kullanıcı Tercih ve Beklentileri}

Her iki bölgede bir önce oturulan konut tipi çoğunlukla apartman dairesidir (A için \%62, B için \%68) ancak daha önce bahçeli müstakil konutta yaşamış olanlar $A$ bölgesinde $\% 45$, B bölgesinde \%41 oranındadır. Daha önceden bahçeli müstakil konutta oturanların, mevcut konutları ile bahçeli ev karşılaştırmalarında, iki bölgede de, mevcut evlerinin soğutma ve ısıtma, aydınlatma, havalandırma, hava kirliliği, görüntü kirliliği açısından daha olumlu olduğunu dile getirenler $\% 75^{\prime}$ in üzerinde çoğunluktadır. Aynı şartlarda bahçeli müstakil bir konutta yaşamak isteyenler iki bölgede de çoğunluktadır. Bununla birlikte binaların bitişik nizam ve bahçesiz yapılaşması yerine bahçeleri olacak şekilde düzenlenmesini isteyenler daha yüksek oranda olup, A bölgesi için \%70, B bölgesi için \%72'dir. Şu anda oturulan konuta taşınma nedenlerinden "mülk sahibi" olmak, her iki bölgede en fazla seçilen etkendir (A bölgesi için \%66, B bölgesi için \%62). A bölgesinde bunu sırasıyla "Erişilebilirlik", "konut çevresi özellikleri" ve "konum" izlerken, B bölgesinde bunu sırasıyla "erişilebilirlik", "sosyal donatı alanlarına yakınlık", " konut çevresi özellikleri" ve "konum" izlemektedir. 
"Şartlarınız uygun olsa hangi konut tipinde oturmayı tercih edersiniz?" sorusuna kullanıcılardan A bölgesinde yaşayanların çoğunlukla (\%42) kent merkezine yakın apartman dairesi yaşamak istediği konut tipidir. Hemen ardından bahçeli müstakil konut (\%38) tercihi gelmektedir. B bölgesinde çoğunlukla istediği bahçeli müstakil konuttur (\%40). Hemen ardından kent merkezine yakın apartman dairesi tercihi (\%32) gelmektedir. Kullanıcıların "Sizce ideal bir konut çevresi nasıl olmalı?" sorusuna A bölgesinde yüksek oranda (\%80) kent içinde merkezi bir bölgede olması, bunun ardından \%16 oranı ile kent dışında, bahçeli ve müstakil bir yerde olması gelmektedir. B bölgesinde ise \%46 oranında geniş, düzenli, bakımlı bir site ortamı içinde olması, bunun ardından $\% 40$ oranında kent içinde merkezi bir bölgede olması gelmektedir. A bölgesinde kentin merkez alanlarına yakın olması, yaşamak istedikleri çevreden beklentilerinde 1. sıradadır. 2. sırada çalışılan yere yakın olması, 3. sırada spor alanı, çocuk bahçesi, park gibi alanların olması gelmektedir. $\mathrm{B}$ bölgesinde çalışılan yere yakın olması, yaşamak istedikleri çevreden beklentilerinde 1. sıradadır. 2. sırada kentin merkez alanlarına yakın olması, 3 . Sırada eğitim alanlarına yakın olması gelmektedir. Her iki bölgede de 4. Sırada, otopark alanların bulunması gelmektedir.

\section{Sonuç}

Kırklareli kent merkezi yapılı çevre özellikleri ile konutkonut çevresi kullanıcı memnuniyeti arasındaki etkileşimin ve kullanıcı beklentilerinin ortaya çıkartı Iması amacı ile ele alınan bu çalışmada, seçilen örneklem bölgelerde tamamlanan analiz ve anket sonuçlarına göre;

Kullanıcı memnuniyetinde olumsuz etkisinin olacağı varsayılan yapılı çevre analiz sonuçları ile anket sonuçlarının, her iki bölgede de konut-konut çevresi memnuniyetinin yüksek olması nedeniyle birbiri ile örtüşür nitelikte olmadığı görülmektedir. Bu sonuç Kırklareli Merkez İlçe kullanıcı karakterini belirleyen, kullanıcı beklentilerinde ön plana çıkan taleplerin önemini göstermektedir.

Kullanıcı farkındalığı ve iki bölgenin yapılı çevre özelliklerine göre kullanıcının konut-konut çevresi değerlendirmeleri detayda incelendiğinde;

- Kullanıcıların evlerini satın alırken veya kiralarken yönlenmesine (güneş alışı) dikkat edip edilmediğine yönelik soruya \%79.6'sı "evet" yanıtını vermiştir. Bu her iki bölgede kullanıcıların konutlarının yönlenmesiyle ve yapılı çevreyle olan ilişkisi ile ilgili bir farkındalığın olduğunu göstermektedir.

- Kullanıcılar A bölgesi için \%80, B bölgesi için \%82 oranında, "binaların konumlanması" nın rüzgârı kestiğini, bununda evlerinin doğal havalandırmasına engel olduğunu dile getirmişlerdir. Bu hem kullanıcıların yapılı çevreyle olan farkındalıklarını hem de yapıların birbirine yakın mesafede yer alması, TAKS/KAKS oranlarının çok yüksek olması, yapı yüksekliklerine göre yol genişliklerinin yeterli olmaması ve hava sirkülasyonu analizleri ile ortaya konan bulguların kullanıcı memnuniyetini doğrudan etkilediğini göstermektedir.

- Anket sonuçlarına göre her iki bölge de "binalar arası mesafe" den memnun olunmadığı belirtilmiştir. B bölgesindeki kullanıııların binalar arasındaki mesafeden A Bölgesine göre daha az memnun oldukları tespit edilmiştir. Bu sonuç analiz bulguları ile paralellik göstermektedir. Kullanıcılar binalar arasındaki mesafenin yaşam koşullarına etkisi olduğunu kabul ettiklerini göstermişlerdir.

- B bölgesinde konut çevresi özelliklerinden "yeşil alan", "çocuk oyun alanı", "araç güvenliği" ve "araç otoparkı var|ı̆̆ı" konularında A örneklem bölgeden daha yüksek memnuniyetsizlik durumu vardır. Bu sonuç yapılı çevre analizlerinden işlevsel kullanım ve TAKS-KAKS analizleri ile örtüşür niteliktedir.

- Anket sonuçlarına göre otopark haricinde "erişilebilirlik" maddelerinin yüksek oranda memnuniyet bulunmaktadır. Bu sonuç kentin küçük ve yürünebilir bir kent olması, kentsel donat alanlarına yürünebilir mesafede erişilebilir olmasının bir göstergesidir. İki bölge konut çevresi işlevsel kullanım verileri ile kısmen örtüşmektedir.

- B bölgesinde, klima ve vantilatör kullanımı doğal havalandırmaya göre daha yüksek orandadır. A örneklem bölgesinde ise eşit orandadır. Hava sirkülasyon analizleri ile örtüşen bu ihtiyacın, mer'i plan şartlarına göre henüz yapılaşması tamamlanmamış olan iki bölgede de daha da artacağı beklenmektedir.

Mekânsal analizler ve anket çalışmaları değerlendirmeleri ile Kırklareli kent merkezi yapılı çevre özellikleri ve konut-konut çevresi kullanıcı memnuniyeti arasında bir etkileşim olduğu ancak, kullanıcı tercih ve beklentilerinin ön planda olduğu görülmüştür.

- Tüm kullanıcılar "şehir yaşantısı"nı tercih etmektedirler. Ancak yaşadıkları yerde binaların bitişik nizam ve bahçesiz yapılaşması yerine, bahçeleri olacak şekilde düzenlenmesini istemektedirler.

- Her iki bölgede de "mülk sahibi" olmak, şu anda oturulan konuta taşınma nedenlerinde en büyük etkendir.

- Merkeze "yakınlık/erişebilirlik" her iki bölgede de konut çevresi memnuniyet nedenini belirleyen en yüksek puana sahip olan maddedir. Aynı zamanda "yaşamak istedikleri çevreden beklentilerinde" de her iki bölgede de "merkeze yakınlık" ve "çalışılan yere yakınlık" yaşanmak istenilen yer için en önemli ve vazgeçilmez özelliktir.

- Kullanıcılar konutlarından ve konut çevrelerinden yüksek oranda memnundur, Ancak memnuniyet duymadıkları noktalar da bulunmaktadır. Bunların başında binalarının manzarasız olması, bitişik düzen olması, en çok da araç park yerlerinin bulunmaması gelmektedir. 
- Memnuniyetsizlikte oranın araç park yerlerinin olmamasında yüksek olması önemli bir talebi ortaya çıkartırken, yaşamak istenilen yerin otopark alanlarına yakın olmasının 4. tercih olarak sıralamaya girmesi, kent merkezinin genel anlamdaki otopark sorununu da gündeme getirmektedir.

- Kullanıcılara en son yöneltilen, şartlarınız uygun olsa Kırklareli'nin hangi bölgesinde ikamet etmek istersiniz sorusuna; çoğunluk mevcut oturdukları yeri istedikleri cevabını vermiştir. Bu konut-konut çevresi memnuniyet oranlarının yüksek çıkmasını da açıklayan önemli bir sonuçtur.

Anket yapılan kullanıcıların eğitim düzeyleri yüksektir, bilinçlidirler ve yaşadıkları yerle ilgili farkındalıkları vardır. Kent yaşamını talep etmektedirler. Kentte de nefes alabilecekleri açık alanların olmasını, bitişik nizam bahçesiz yerine, konutların bahçeli olarak düzenlenmesini istemektedirler. Ancak yaşanılan yerin fiziksel diğer tüm özelliklerinin ötesinde hem işyerlerine hem merkeze yakın bölgede yaşama istekleri ön plandadır.

Bu makale sonuçları itibariyle, Kırklareli merkez ilçesi gibi düzensiz ve kontrolsüz mekânsal gelişim özelliği taşıyan kentlerde, konut ve konut çevresi memnuniyetinin belirlenmesinde yaşayanların tercih ve beklentileri ile birlikte mekânsal gelişimdeki etkenlerin de tartışımaya açılmasını gündeme getirmektedir. Yeni gelişme alanlarının kullanıcı tercihleri dikkate alınarak planlanması kullanıc memnuniyetini arttracaktır.

\section{Kaynaklar}

Aysu, E., Ökten, A., Ünal, Y., Görgülü, Z., Dinçer, Y., Karahasanoğlu, I., Tavşanoğlu, S., (1984) Kırklareli Kentsel Yapı Araştırması (Kent Monografisi). Yıldız Teknik Üniversitesi Şehir ve Bölge Planlama Bölümü Yayını.

Berköz L. (2008) İstanbul'da Korunaklı Tek-Aile Konutları: Konut Kalitesi Ve Kullanıcı Memnuniyetinin Belirlenmesi, ITÜ Dergisi/A, Mimarlık, Planlama, Tasarım Cilt:7, Sayı:1, 110-124 Mart 2008.

Bölen, F, Türkoğlu, H.D., Ergun, N., Yirmibeşoğlu, F., Kundak, S., Terzi, F. ve Kaya, S., (2006) “istanbul'da Konut Alanlarında Fiz. Çevre Kalitesi Analizi" IMP Konut ve Yasam Kalitesi Grubu Raporu, Cilt 1, ist.

Dülgeroğlu Y., Aydınlı, S., Yılmaz, Z. ve Pulat, G., (1996) Toplu Konutlarda Nitelik Sorunu. T.C.Başbakanlık Toplu Konut Idaresi. Konut Araştırmaları Dizisi 4, ODTÜ Basım Cilt 1-2, Ankara.

Gündoğdu M. Altın Y. (2015) "Kırklareli Kent Formu ve Arazi Değerleri Ilişkisi" Türkiye Kentsel Morfoloji Sempozyumu (Temel Yaklaşımlar ve Teknikler) 22-23 Ekim 2015, Sempozyum Kitapçığı Ekim 2016, Mersin Üniversitesi Yayınları no: 44 Akdeniz Kent Araştırmaları Merkezi Yayınları no: 5 ISBN: 978-9756900-52-9.

Güremen, L., (2011) Müstakil Villa Tipi Konutların Kullanıcı Mem- nuniyetini Belirleyen Özellikleri: Niğde Kenti Özelinde Bir Araştirma. E-Journal of New World Sciences Academy, Volume: 6, Number: 3, Article Number:1A0190, ISSN:1306-3111.

Güremen, L., (2016) Konut Ve Yerleşim Alanı Kullanıcı Algııının Memnuniyet Ve Tercih Davranışına Etkisi Üzerine Bir Araştırmada Amasya Örneği, Technological Applied Sciences (Nwsatas) 2016; 11(2): 24-64.

İmamoğlu, V., (1996) İnsan, Evi ve Çevresi Araştırma Projesi; Mimari Bazı Gözlemler, Konut Araştrmaları Sempozyumu, 1-2 Temmuz 1993, Konut Araştırmaları Dizisi:1, Ankara, s.349366.

Kellekci, Ö.L. ve Berköz, L., (2006) Konut ve Çevresel Kalite Memnuniyeti Yükselten Faktörler, iTÜ Dergisi/A, Mimarlık, Planlama, Tasarım, 5(2), 167-178, Eylül 2006.

Mimar Sinan Güzel Sanatlar Üniversitesi (MSGÜ), (1991) Kırklareli Analitik Etüt Raporu. İstanbul: MSGÜ, ŞBP Bölümü, 1991.

Mississagua, (2014) Urban Design Terms of Reference: Standards for Shadow Studies, Kanada.

Önder, D. E., Köseoğlu, K, Bölen, O, (2010) “The Effect Of User Participation In Satisfaction: Beyciler After-Earthquake Houses in Düzce", ітÜ Dergisi/A, Mimarlık, Planlama, Tasarım, Vol:7 No:1, ss. 18-37.

Özkök, M. K., (2016) Kentsel Yerleşimin, Kentsel Politikalar ve Sürdürülebilir Planlama Yaklaşımı Kapsamında Değerlendirilmesi: Kırklareli Örneği. Yayımlanmamış Yüksek Lisans Tezi. Yıldız Teknik Üniversitesi, İstanbul.

Rapaport, A., (1977) Human Aspects Of Urban Form, New York, Pergamar Press.

Trakyaka (Trakya Kalkınma Ajansı), (2012); Tr21 Trakya Bölgesi Enerji Raporu, Edirne: Trakyaka.

Tuncel M., (2002) Türkiye illeri Ansiklopedisi Kırklareli Bölümü TíA Cilt 25, sf: 480-481.

Ünlü, T., (2006) Kentsel Mekanda Değişimin Yönetilmesi METU JFA 2006/2 (23-2) 63-92.

Yıldız, E., Ulusoy M. (2014) Yeni Konutlaşma Eğilimi Olan Dışa Kapalı Konut Yerleşmelerinde Kullanıcı Memnuniyeti Analizi: Konya Örneği, Selçuk Üniversitesi Mühendislik Bilim ve Teknoloji Dergisi., c.2, s.3, 2014. ISSN: 2147-9364.

Zorlu, T., Sağsöz, A. (2010) “Müstakil Konut Sitelerinde Kullanıcı Tercihlerine Bağlı Fiziki Müdahaleler, Trabzon Örneği" METU JFA cılt: 27 sayı:2, ss. 190-205.

\section{Internet Kaynakları}

Planlı alanlar Tip İmar Yönetmeliği: http://www.resmigazete.gov. $\operatorname{tr}$ (18.12.2018).

Mekânsal Planlar Yapım Yönetmeliği: http://mevzuat.basbakanlik.gov.tr/ (12.12.2017).

Türkiye İstatistik Kurumu Adrese Dayalı Nüfus Kayıt Sistemi: http://www.tuik.gov.tr/ (18.01.2017).

Kırklareli Kent Merkezi İklim Özellikleri: https://www.havaturkiye.com/Turkiye/Kirklareli.htm (18.12.2018).

Kırklareli Kent Merkezi Iklim Verileri: https://www.weatheronline.co.uk/Turkey/Kirklareli.htm (18.12.2018). 